\title{
Animal carcass burial management: implications for sustainable biochar use
}

Meththika Vithanage ${ }^{1 *}$, S. S. Mayakaduwage ${ }^{1,2}$, Viraj Gunarathne ${ }^{1}$, Anushka Upamali Rajapaksha1, Mahtab Ahmad ${ }^{3}$, Adel Abduljabbar ${ }^{4}$, Adel Usman ${ }^{5}$, Mohammad I. Al-Wabel ${ }^{5}$, James A. Ippolito ${ }^{6}$ and Yong Sik Ok ${ }^{7^{*}}$

\begin{abstract}
This review focuses on existing technologies for carcass and corpse disposal and potential alternative treatment strategies. Furthermore, key issues related to these treatments (e.g., carcass and corpse disposal events, available methods, performances, and limitations) are addressed in conjunction with associated environmental impacts. Simultaneously, various treatment technologies have been evaluated to provide insights into the adsorptive removal of specific pollutants derived from carcass disposal and management. In this regard, it has been proposed that a low-cost pollutant sorbent may be utilized, namely, biochar. Biochar has demonstrated the ability to remove (in)organic pollutants and excess nutrients from soils and waters; thus, we identify possible biochar uses for soil and water remediation at carcass and corpse disposal sites. To date, however, little emphasis has been placed on potential biochar use to manage such disposal sites. We highlight the need for strategic efforts to accurately assess biochar effectiveness when applied towards the remediation of complex pollutants produced and circulated within carcass and corpse burial systems.
\end{abstract}

Keywords: Pandemic, Soil amendment, Carcass burial, Human corpses, Biochar

\footnotetext{
*Correspondence: meththika@sjp.ac.lk; yongsikok@korea.ac.kr

1 Ecosphere Resilience Research Centre, Faculty of Applied Sciences,

University of Sri Jayewardenepura, Nugegoda 10250, Sri Lanka

${ }^{7}$ Korea Biochar Research Center, APRU Sustainable Waste Management

and Division of Environmental Science and Ecological Engineering, Korea

University, Seoul 02841, South Korea

Full list of author information is available at the end of the article
} original author(s) and the source, provide a link to the Creative Commons licence, and indicate if changes were made. The images or other third party material in this article are included in the article's Creative Commons licence, unless indicated otherwise in a credit line to the material. If material is not included in the article's Creative Commons licence and your intended use is not permitted by statutory regulation or exceeds the permitted use, you will need to obtain permission directly from the copyright holder. To view a copy of this licence, visit http://creativecommons.org/licenses/by/4.0/. 


\section{Graphical Abstract}

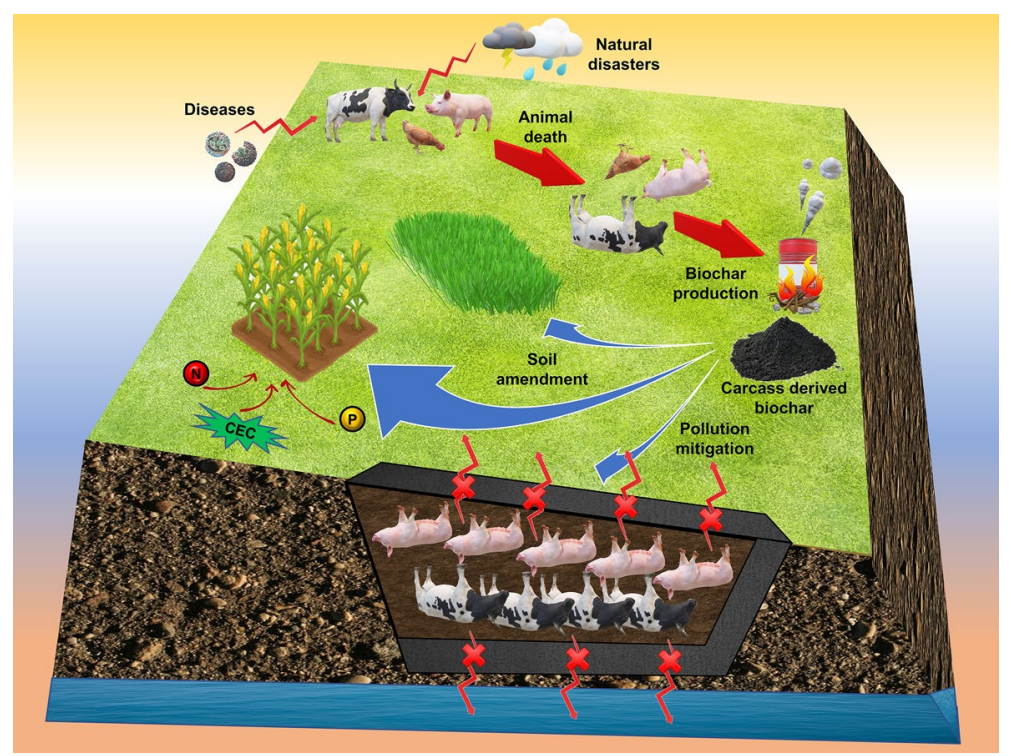

\section{Introduction}

Recently, a growing global concern over the safe and proper disposal of mass carcasses and corpses due to pandemics, epidemics, natural disasters, and wars has arisen. Specifically, at the time of writing, more than 100 countries are facing mass grave or corpse burial issues related to the COVID-19 pandemic. Presently, several countries (e.g., USA, Iran, Italy) are utilizing mass grave burial, while others (e.g., South Africa) are still at an early stage to consider such a disposal means due to rising death tolls from the infectious SARS-CoV-2 contagion. In 2004, one of the most disastrous tsunamis occurred in the Indian Ocean, affecting over 14 countries and killing 230,000 human beings [1]. Mass burial is the only fatality management option following pandemics or natural disasters such as these [2].

Similarly, yet much less notable by the public, animal agricultural operations have identical concerns to those above. Animal agriculture, with a global livestock population of approximately $1.9 \times 10^{10}$ birds and $2.31 \times 10^{8}$ mammals, continuously generates significant carcass volumes that need to be disposed of in a diligent and environmentally responsible manner [3]. For example, the U.S. livestock industry annual production of animal by-products and animal mortality is approximately $2.85 \times 10^{10} \mathrm{~kg}$ [4]. In Europe, approximately $3.4 \times 10^{9} \mathrm{~kg}$ of animal carcasses are reported to remain following human consumption [5]. China produces $20 \times 10^{5}$ pig carcasses annually, with this number increasing yearly [6]. The above mentioned numbers, being already considerably high, become greater in the event of disease outbreaks, natural disasters, or other accidents. According to recent data, 32 million livestock units (LSU) die annually due to foot-and-mouth disease (FMD) [7]. In Korea alone, nearly $3.4 \times 10^{6}$ of swine and bovine were slaughtered and buried between 2010 to 2011 due to FMD $[8,9]$. In Russia, from 2007 to 2012 , over $6.0 \times 10^{5}$ pigs were killed or culled due to swine flu [10]. In 2014, avian influenza caused approximately $7.0 \times 10^{6}$ poultry deaths in Korea [11]. In 2010, extreme weather conditions in Mongolia were accompanied by significant livestock mortality that accounted for $\sim 20 \%$ of the national herd [12]. The above numbers strongly indicate measures for proper carcass disposal in lieu of environmental safety measures to prevent the spread of disease and contamination of soil and groundwater.

Many authors have reported potential contamination in soil and groundwater systems from mass carcass burial due to organic components (biological oxygen demand (BOD), total organic carbon (TOC), inorganic compounds (e.g., total dissolved solids (TDS), chloride, ammonia, and nitrate), and many other substances (e.g., enteric pathogens, steroid hormones, and antibiotics) $[8,13-15]$. In terms of human deaths, the environmental threats posed by mass burial events due to wars, natural disasters or pandemics may be less anticipated than animal carcass disposal events. When human death rates reach historic highs, mass burial often becomes the only viable option [16]. Mass burial events have led to groundwater contamination by hazardous leachate plumes generated by human 
Table 1 Carcass and corpse disposal events in the world

\begin{tabular}{|c|c|c|c|}
\hline Country & Disposal events & Disposal method & Reference \\
\hline \multicolumn{4}{|c|}{ Carcass disposal events } \\
\hline \multirow[t]{8}{*}{ USA } & Routine mortalities & Burial, Composting, Rendering & {$[11,32,36]$} \\
\hline & Hurricane Floyd & Burial, Incineration, Composting, Rendering & {$[13,34]$} \\
\hline & Texas Flood & Burial, Incineration & {$[34]$} \\
\hline & Exotic Newcastle Disease (END) & Burial & [13] \\
\hline & Severe winter and flood & Burial, Incineration & [13] \\
\hline & Avian influenza (Al) & Burial & [13] \\
\hline & A chemical poisoning incident & Burial & [13] \\
\hline & A fire accident & Burial & [13] \\
\hline Taiwan & Foot-and-mouth disease (FMD) & Burning, incineration, Rendering & {$[34,149]$} \\
\hline \multirow[t]{3}{*}{ UK } & Bovine spongiform encephalopathy (BSE) & Burial & {$[36]$} \\
\hline & FMD & $\begin{array}{l}\text { Burial } \\
\text { Rendering } \\
\text { Burning } \\
\text { Incineration } \\
\text { Composting }\end{array}$ & {$[13,14,36]$} \\
\hline & $\mathrm{Al}$ & Incineration, Rendering & [150] \\
\hline \multirow[t]{3}{*}{ Korea } & FMD & Burial & [94] \\
\hline & Al & Burial & [94] \\
\hline & Routine mortality & Burial, Rendering, Incineration & {$[11,94]$} \\
\hline Japan & FMD & Burial & [151] \\
\hline Canada & Al and END & Composting & [152] \\
\hline Netherlands & $\mathrm{FMD}$ and $\mathrm{Al}$ & Incineration, Composting & [150] \\
\hline Hong Kong & Al & Incineration, Composting & [150] \\
\hline \multicolumn{4}{|c|}{ Mass corpse disposal events } \\
\hline Rwanda & Genocide violence & Burial & [31] \\
\hline Southeast Poland & World War I and II & Burial & {$[29]$} \\
\hline Britain & World War II & Burial & [153] \\
\hline Spain & Civil War & Burial & [154] \\
\hline Haiti & Earthquake & Burial & [155] \\
\hline Thailand & Tsunami & Burial, Cremation & [30] \\
\hline
\end{tabular}

corpse decomposition [17]. However, the risk of spread of pathogenic organisms through groundwater contamination is of high concern [18]. In terms of animal fatalities, a few studies have focused on mass livestock burial correlations with groundwater contamination, suggesting a need for site-specific contaminant removal technologies $[8,15]$. Environmental remediation in the vicinity of mass burial sites should be made via costeffective methods.

A potential cost-effective tool for addressing environmental remediation of mass burial sites may simply be biochar; biochar has been recognized as an effective, bio-secure, and economically viable approach for addressing the environmental repercussions of animal disposal techniques [19]. Biochar has also been proven to have potential for remediation of pathogen [20], ammonium nitrogen [21], nutrients [22], heavy metals [23], BOD [24], chemical oxygen demand [25], antibiotics [26], and steroid hormone [27] in aqueous/ soil media. In this review, we (1) provide a concise and up-to-date overview of carcass management techniques along with their environmental implications, (2) emphasize the significance of biochar use for overcoming carcass management issues, and (3) suggest future research directions.

\section{Disposal events and technologies for carcasses and corpses}

Mass carcass and corpse disposal events

All animal mortalities, including routine animal mortalities or large animal carcass quantities resulting from 
Table 2 Contaminants derived from different carcass and corpse disposal technologies

\begin{tabular}{|c|c|c|}
\hline Disposal method & Major contaminants & Reference \\
\hline \multicolumn{3}{|l|}{ Carcass disposal technologies } \\
\hline Burial & $\begin{array}{l}\text { BOD } \\
\text { Ammonia-nitrogen } \\
\text { TDS } \\
\text { Chloride } \\
\text { Alkalinity } \\
\text { Sulfate } \\
\text { COD } \\
\text { Steroid hormones } \\
\text { Antibiotics }\end{array}$ & {$[13,32,46,156,157]$} \\
\hline Open burning and incineration & $\begin{array}{l}\text { Dioxin } \\
\text { Polycyclic aromatic hydrocarbons } \\
\text { Smoke/ash } \\
\text { Heavy metals }(\mathrm{Cd}, \mathrm{Pb})\end{array}$ & {$[65,68,69,158]$} \\
\hline Anaerobic digestion & $\begin{array}{l}\text { Pathogens } \\
\text { Greenhouse gases }\end{array}$ & [78] \\
\hline Alkaline hydrolysis & Alkaline effluents & [79] \\
\hline Composting & $\begin{array}{l}\text { Ammonia-nitrogen } \\
\text { TOC }\end{array}$ & [93] \\
\hline \multicolumn{3}{|l|}{ Corpse disposal technologies } \\
\hline Burial & $\begin{array}{l}\text { Methane } \\
\text { Hydrogen sulfide } \\
\text { Ammonia } \\
\text { Phosphine } \\
\text { Volatile amines (putrescine and cadaverine) } \\
\text { Mercaptans } \\
\text { Heavy metals }\end{array}$ & {$[29,31,49,51,56,58]$} \\
\hline Cremation & $\begin{array}{l}\text { Particulate matter } \\
\text { Sulfur dioxide } \\
\text { Oxides of nitrogen } \\
\text { Carbon monoxide } \\
\text { Hydrochloric acid } \\
\text { Hydrofluoric acid } \\
\text { Ammonia } \\
\text { VOCs } \\
\text { Heavy metals } \\
\text { Polychlorinated dibenzo-p-dioxins } \\
\text { Dibenzofurans }\end{array}$ & {$[71,72,159]$} \\
\hline
\end{tabular}

hazardous events or disease-related disasters, should be disposed of in a timely, efficient, and safe manner in order to minimize negative environmental impacts. The selected method of disposal may be based on several factors, such as type and quantity of animal carcasses, location, cause of mortality, and economic status [28]. A combination of methods is often required to accomplish carcass disposal, especially during times of significant loss. This may lead to rapid and effective disease eradication. Table 1 summarizes mass carcass and corpse disposal events recorded in different countries, and the disposal methods implemented.

\section{Mass carcass and corpse disposal technologies}

The most widely used mass animal carcass and human corpse disposal methods are burial and incineration, that have been used for pandemics, wars and natural catastrophic events $[29,30]$. Owing to land scarcity, many countries utilize mass graves for corpse disposal due to aforementioned catastrophic events [31]. However, anaerobic digestion, rendering, alkaline hydrolysis, composting, and hydrothermal conversion are only used for animal carcass disposal. Different carcass disposal practices are attributed with various environmental problems; the release of leachates containing hazardous chemical compounds, pathogenic organisms, or gaseous emissions, have been identified as major environmental issues. Table 2 summarizes types of pollutants 
derived from different carcass/corpse disposal technologies, while specific technologies and associated issues are described in detail below.

\section{Burial}

Land burial is one of the most common and traditional disposal methods for both daily and catastrophic animal mortalities. However, this technique has also been used for corpse disposal resulting from wars or natural catastrophic events. For example, mass corpse burial was extensively utilized during World Wars I and II [29]. Land burial is preferred due to the limited infrastructure requirements, minimal disposal costs, and owners' convenience [32]. Trench-type burial, landfill-type mass burial, or small on-farm burial is commonly deployed in different areas globally [33]. However, proper site selection, trench design, and site maintenance should be in accordance with the criteria established by relevant authorities to ensure minimum environmental risk. For example, burial should not take place within $350 \mathrm{~m}$ of surface water, or any private or public drinking water wells, or within the boundaries of river floodplains [34]. Carcasses should be placed in an approximately 0.9$1.2 \mathrm{~m}$ deep compacted trench, and the trench should be covered with mounded soil. Monitoring, together with personnel/equipment safety precautions, should also be required. According to research, carcass burial may have detrimental environmental impacts, resulting in soil, water and air pollution $[35,36]$. Thus, carcass land burial is banned in the European Union and in some parts of the USA. In areas where this practice is allowed, strict legislation has been enacted to maintain limitations $[14,36]$. Nevertheless, in most cases, burial is still permitted for catastrophic mortality events.

Carcass and corpse burial issues Despite the fact that burial is the most common carcass/corpse disposal method, and is highly applicable when large numbers are involved, only a few sites may provide the appropriate soil and hydraulic properties for environmentally safe burials. The areas situated within close proximity to surface water sources, roads, human settlements and soil associated with shallow groundwater tables have been considered unsuitable for burial sites [37]. There is a high probability for contaminants to enter the surrounding soil, groundwater, or atmosphere when burial pits are made by disregarding the guidelines provided by respective authorities. Several studies have reported soil and groundwater leachate and atmospheric gas contamination associated with carcass burial sites [33, 38, 39]. Negative effects from carcass burial on shallow groundwater have been reported [13]. It has been estimated that resulting groundwater contamination can persist for $\sim 20$ years due to prolonged carcass decomposition timeframes [33]. According to a study conducted by Watkiss and Smith [39], about 10 years were required to decompose buried livestock carcasses, while the leachate release remained constant for over 20 years [38, 39]. The major reasons for groundwater contamination with releasing leachates have been identified as improper construction of burial pits, damages to liners and rising groundwater tables [37]. Significant greenhouse gas emissions from U.S. animal carcass land burial systems have also been reported [36]. Improperly managed carcass burial sites may also pose a poisoning threat to wildlife and fish populations [33]. Salcedo and Kim [40] found that carcass leachates can act as a point source for generating antibiotic resistant microbial strains. Due to the negative environmental effects, it should be emphasized that while burial places the problem "out-of-sight, out-of-mind", it does not mean an end to the problem [13].

Site-specific concerns for carcass disposal regarding explicit contaminants are also increasing [13, 32, 41]. Several case studies have detected elevated levels of BOD, ammonia-nitrogen, TDS, and chloride in close proximity to burial sites [13, 42, 43]. Groundwater contamination with ammonia, nitrate, chloride, and fecal pathogens discharged from carcass disposal pits has also been reported [38, 44, 45]. Similarly, McArthur and Milne [46] observed a total of $4,000 \mathrm{~m}^{3}$ of leachate generated with elevated BOD, COD, alkalinity, and ammonia-nitrogen from a burial site of FMD carcasses [46]. Elevated BOD $\left(230 \mathrm{mg} \mathrm{L}^{-1}\right)$, ammonia-nitrogen (403 $\mathrm{mg} \mathrm{L}^{-1}$ ), TDS (1527 $\left.\mathrm{mg} \mathrm{L}^{-1}\right)$, and chloride (109 mg $\mathrm{L}^{-1}$ ) were detected in groundwater samples collected from an area near disposal pits which contained $28,400 \mathrm{~kg}$ turkey carcasses and 6 swine carcasses [47]. Yuan et al. [32] detected steroid hormones, antibiotics, and other nutrients associated with the land burial of cattle carcasses.

Mass human corpse burial induces comparatively similar environment-related hazards to mass animal carcass burial. The specific soils associated with corpse burial sites are called "Necrosols" [48]. Typically, necrosols often become enriched with organic and inorganic nutrients, and have been observed to release volatile gases including ammonia, methane and hydrogen sulfide [49-51]. Decomposition of a human corpse generates approximately $0.4-0.6 \mathrm{~L}$ of leachate for each kilogram of body weight, and at a density of $1.23 \mathrm{~g} \mathrm{~cm}^{-3}$ [52] can lead to downward pollutant movement. This leachate is characterized by high $\mathrm{BOD}, \mathrm{pH}$, conductivity and chemical compounds including phosphorus, nitrogen, $\mathrm{Na}^{+}$, 
$\mathrm{Ca}^{2+}, \mathrm{Cl}^{-}, \mathrm{HCO}_{3}^{-}$, and $10 \%$ organic compounds $[18,53]$. Necrosols also have the possibility to be contaminated with heavy metals such as $\mathrm{Pb}, \mathrm{Cr}, \mathrm{Zn}, \mathrm{As}, \mathrm{Mo}$, and $\mathrm{Cu}$ through the decomposition of paints, preservatives and metallic components from coffins [54, 55] Amuno [31] found slightly higher concentrations of 12 trace elements (As, Ba, Cr, Cs, Ga, Ni, Rb, Sc, Th, V, Y, and Zr) in soil of mass grave sites in Rwanda compared to offsite soils. However, that study revealed that the elemental concentrations were not great enough to generate any environment concern. Spongberg and Becks [56] observed elevated heavy metal concentrations $(\mathrm{Pb}, \mathrm{Cu}, \mathrm{Zn}, \mathrm{Co}, \mathrm{As}$, and $\mathrm{Fe}$ ) in a cemetery necrosol situated in Ohio, USA. Moreover, the mass burials used for disposal of soldier corpses typically contain badges, weapons, buttons, etc., that can release heavy metals and other toxic chemicals to the soil and groundwater [29].

Pathogen release to groundwater and surrounding soil is one of the major concerns of carcass/corpse burial. Pathogenic microorganisms including Enterobacteriaceae, Bacilli, Streptococci, Staphylococci, and Clostridia are associated in human tissues, and can act as potential contaminants if released through corpse decay $[57,58]$. However, during a pandemic event, potential high risk for spreading virulent microorganisms would be associated with corpse burial regardless of the pathogenic survivability in the soil environment [58]. Favorable environmental conditions such as low temperature, alkalinity, high organic matter and moisture content may increase pathogenic survivability [59]. Prolonged survivability is especially true for spore-forming bacteria species including Clostridium sp., which have the ability to survive long time periods even under unfavorable environmental conditions [18, 60]. Abia et al. [61] suggested that corpse burial sites would be a source for microbial pollution in groundwater. The most important bacteria that can pose health risk via transportation with water sources include Shigella sp., Salmonella sp., E.coli, Yersinia enterocolitica, Y. pseudotuberculosis, Leptospira sp., Dyspepsia coli, Francisella tularensis, Vibrio sp., Pseudomonades, and Legionella sp.; viruses include hepatitis virus, Coxsackie viruses, polio virus, adenovirus, Norwalk-like virus and rotavirus [62]. Because of these reasons, mass land carcass and corpse burial during and after pandemics/epidemics should be carried out with extreme caution to prevent further environmental spread.

\section{Open burning and incineration}

The open burning of animal carcasses is another commonly used disposal method in many countries. Livestock carcass burning was used during disease epidemics, such as UK FMD outbreak (2001) and the Ugandan anthrax outbreak (2004/2005) [14]. Incineration and cremation are especially suitable for carcass/ corpse disposal to prevent further spread of pathogenic organisms resulting from epidemic or pandemic events. For example, cremation has been recommended by China, Sri Lanka, India and USA governments for corpse disposal resulting from the COVID-19 pandemic. Although open burning historically played an important role, now it has become a controversial option for carcass management. In many circumstances, carcass burning should be accomplished in compliance with a waste management license, registered waste exemption, or permit related to pollution control. Furthermore, important considerations such as site location and accessibility, type of animal carcass involved, fuel availability, carcasses quantities to burn, and environmental conditions, should be taken into account [34]. Following burning, it has been recommended that the ashes should be buried and the area should be cleaned, graded, or plowed within $48 \mathrm{~h}$ [63].

When open burning, it is not always possible to achieve complete carcass burning, which can lead to increased toxic emissions and infection risks. Thus incineration, where animal carcasses are burnt at high temperatures $\left(\geq 850^{\circ} \mathrm{C}\right)$, is considered to be biologically safer than open burning. Incineration should be carried out in a specific unit operating in compliance with local laws and ordinances [14]. Pyrolysis, gasification, or other thermal treatment processes resulting in an organic ash that is expected to be free of infective agents may be considered in replacement of incineration [14, 64]. Organic ash produced from a typical carcass incinerator represents $1-5 \%$ of the input volume, and substantially reduces the environmental footprint associated with carcass disposal [65]. However, incineration gas emissions are a concern, especially under circumstances where the technology may fail to meet environmental standards. Capacity constraints, as well as capital and maintenance costs, are other possible limitations associated with incineration. Carcass moisture content also adds to the energy requirements and costs, thereby making incineration infeasible for routine mortalities. Although incineration is a viable option for the disposal of limited carcass quantities, the cost is insurmountable for large mortalities or catastrophic events [14].

Open burning and incineration issues Open burning or incineration of animal carcasses under inadequate operating conditions or incomplete burning can cause emissions as dioxin, hydrocarbons etc. It has been estimated that dioxins released from animal incineration constituted $0-5 \%$ of total dioxin emissions in the UK [66] In 
addition, a study by Chen et al. [65] calculated the emitted total polycyclic aromatic hydrocarbons (PAH) by carcass incineration during the FMD outbreak in Taiwan in 1997 as $226.2 \mathrm{~kg} \mathrm{day}^{-1}$.

The ash from open burning can be transported by wind, and not only contaminated soils and waters, but may enter the human food chain. Although the released dose is low, long term exposure to these chemicals have increased the risk of low birth weight and congenital anomaly in babies born close to pyre sites $[66,67]$. In Belgium, elevated levels of dioxin, $\mathrm{Pb}$ and $\mathrm{Cd}$ were found in blood samples from children living close to waste incinerators [68]. Similarly, Dummer et al. [69] found an enhanced risk of lethal congenital anomaly in relation to incinerator proximity. Another negative impact is that burning smoke can be a contributor to climate change [70].

Similarly, corpse cremation is known to produce a range of environmental pollutants including $\mathrm{SO}_{2}, \mathrm{CO}$, $\mathrm{NO}_{\mathrm{X}}$, VOCs, $\mathrm{NH}_{3}$, polychlorinated dibenzo- $p$-dioxins, dibenzofurans, particulate matter, and heavy metals [71, 72]. In some regions of the world, low chimney height of standard crematories can lead to pollutant dispersal at or near the ground level, potentially affecting human health $[73,74]$. Therefore, public concern over cremation is rising in countries like China where cremation is utilized for approximately $47 \%$ of corpses [72].

\section{Anaerobic digestion}

Anaerobic digestion is the degradation of organic material by a mixed culture bacterial ecosystem under anaerobic conditions. Biogas (methane), liquid and solid fertilizers are the final products of anaerobic digestion. In Europe, anaerobic digestion has been successfully used as a viable option for large animal carcass management (e.g., dairy/beef cattle, swine) [75]. Anaerobic digestion produces useful bioenergy in the form of methane [14]. For mesophilic or moderate temperature digestion, a digester temperature of $35^{\circ} \mathrm{C}$ with a retention time of $15-20$ days is common. For thermophilic digestion, the digester is adjusted to $55{ }^{\circ} \mathrm{C}$ with a retention time of $12-14$ days [76]. However, it has been found that the operational temperature of thermophilic digestion is not high enough to kill pathogens, such as transmissible spongiform encephalopathies [14]. Unfortunately, some researchers suggest that on-site dairy cattle carcass disposal via anaerobic digestion is suitable only for very large operations, due to the significant infrastructure costs [75]. Although anaerobic digestion of large animal mortalities is technically feasible, site-specific variables, such as the economic value of methane production and cost of other available disposal methods, should be considered before implementation.

Anaerobic digestion issues Although anaerobic digestion has been considered as a cost effective and energyrenewable technology, it may not be capable of degrading more resilient pathogens such as Bacillus anthracis [77]. According to Maynaud et al. [78], Campylobacter coli and Listeria monocytogenes can regrow after land application, leading to public health hazards, especially if the digestate is not properly treated with chemical additives or pasteurization prior to or during land application [78]. In addition, intermediate-chemical accumulation, such as volatile fatty acids generated under unstable operating conditions, may lead to environmental toxic effects including acidification and heavy metal accumulation in digested products [79]. Moreover, greenhouse gas production (e.g., methane and carbon dioxide) may occur during anaerobic carcass digestion, contributing to global warming [13].

\section{Rendering}

Rendering is the process of converting animal carcasses into value-added products, such bone meal and animal fat. It is primarily a heat-driven process by which carcasses are exposed to high temperatures in order to accomplish material physicochemical transformations and pathogen destruction. The traditional rendering method uses pressurized steam in large closed tanks followed by a grinding process. As an alternative to this, a new method of dry cooking the material in its own fat by dry heat in open steam-jacketed drums has been introduced [34]. The temperature and time are commonly selected based on the raw material composition, and are primary determinants of final product quality. Recovered animal fats and proteins are used industrially, or as valuable ingredients to sustain animal agriculture. Rendering is considered one of the most environmentally sound disposal methods, because if properly managed, it facilitates recycling and beneficial reuse of materials that otherwise would be considered waste [34].

Rendering related issues When infrastructure is available, rendering is considered a very effective, convenient, and economical disposal method for carcasses, as well as having the advantage of yielding marketable products. Nevertheless, biosecurity and disease transmission risks are major rendering concerns with the rendering method. Rendered byproducts may also contain transmissible bovine spongiform encephalopathies. Thus, the rendering industry should assume responsibility for maintaining raw material controls, ensuring final product(s) bio-safety, and gaseous or liquid effluent 
management according to local, regional, or countrywide regulations [80].

\section{Alkaline hydrolysis}

Alkaline hydrolysis was introduced in the 1990s as a new carcass disposal technology. It is carried out by converting animal carcasses to a sterile aqueous solution of amino acids, sugars, and soaps, using alkali at elevated temperatures [34]. Enzymes, metal salts, acids or bases can be used as catalysts for the hydrolysis process. Among them, alkaline hydrolysis can occur in fixed or mobile facilities, where carcasses are placed in sealed containers with solid or solution type alkali (14). Heat $\left(150{ }^{\circ} \mathrm{C}\right)$ is typically applied and the process is maintained for up to six hours in order to increase degradation processes $[13,14]$. The resulting effluent consists of a nutrient rich sterile liquid and bone residue, both of which may be used as soil amendments [13, 81, 82].

By using alkaline hydrolysis, most negative public perceptions associated with carcass disposal can be avoided, as the process inactivates pathogens, sterilizes, and yields environmentally safe materials. Alkaline hydrolysis was the preferred disposal method for bird carcasses infected with avian influenza H5N1 [83]. However, large scale alkaline hydrolysis use may only be feasible for relatively small carcass sizes (birds instead of cattle). The large initial investment cost, expensive maintenance, and limited capacity for large volume carcasses limit the wide use of alkaline hydrolysis for carcass disposal [34].

Alkaline hydrolysis related issues The disinfected solid fraction remaining after alkaline hydrolysis treatment is disposed of in solid waste landfills. However, the liquid effluent generated from this treatment may have a high $\mathrm{pH}$ and high organic compound concentrations [79]. Discharge of these effluents into water sources may pose negative environmental impacts. It has been reported that alkaline $\mathrm{pH}(8.5-10)$ causes ammonia toxicity to most fish. Further, alkaline leachates may lead to precipitation of calcite [84]; if these precipitates enter water bodies, they can smother aquatic habitats (including benthic and littoral) and reduce light penetration to primary benthic producers [85]. Another significant issue is that trace metals that form oxyanions (e.g. As, Cr, Mo, Se, V) can be highly mobile in alkaline waters, and thereby may pose different environmental and biological threats [86].

\section{Other techniques}

In addition to the commonly approved disposal methods mentioned above, composting, fermentation, hydrothermal conversion, dry extrusion, refeeding to scavengers, and ocean disposal are other carcass management forms $[14,34]$. Although these methods are not applicable for catastrophic events, they are occasionally utilized by the private, agriculture, or business sectors.

Composting is a controlled, aerobic decomposition process that relies on beneficial microorganisms, such as bacteria and fungi. Under optimal conditions, these microbes may decompose carcasses into a humus-like material useful as an organic soil amendment, slow release fertilizer, or water-saving mulch [34]. However, some spore-forming bacteria and prions may persist after composting, presenting a risk to animals grazing in pastures treated with carcass compost. Consequently, many countries have prohibited composting of large or causative animals [77]. Furthermore, although composting is considered an inexpensive, environmentally sound, easy and universal disposal method for biological waste, according to legislation in many countries, composting is not allowed when biosecurity is an issue. Biosecurity agencies in the USA, Australia, New Zealand and Canada have identified the potential for composting as only an emergency livestock mortality management practice [87]. Despite this, an advanced bio-secure composting techniques can still be effectively used for carcass management when the situation requires emergency disposal. This technique utilizes passively aerated composting systems wrapped with plastic to ensure secure composting without environmental release of virulent organisms [88].

Fermentation is a possible method to ensure material stabilization and pathogen reduction. In this method, carcasses are ground to fine particles, mixed with a fermentable carbohydrate source and culture inoculant, and then added to a fermentation container [13]. This allows for carcass preservation until rendering, by using low $\mathrm{pH}$ conditions which prevent undesirable degradation processes. The major drawback of fermentation is the high initial investment cost [13].

Hydrothermal conversion may be another promising carcass disposal method, during which animal waste is converted into a liquid product. This liquid is often called bio-oil or bio-crude, created under high-pressure thermochemical process conditions. The advantage of this method has been associated with waste-to-fuel energy recovery as high as $80 \%$. Recently, swine carcasses have been successfully converted into bio-oil that could be upgraded to liquid transport fuels [89]. Furthermore, hydrothermal conversion of animal parts may generate bioactive compounds such as keratins and bioactive peptides that can be used as agricultural fertilizers [90, 91]. However, the strict process conditions and high 
investment cost pose a significant obstacle to its worldwide use.

Dry extrusion yields usable byproducts, such as feed ingredients, using friction as a means of creating heat, shear, and pressure. This method is also effective enough to inactivate most pathogens, yet the associated high capital cost is a major drawback [92]. Refeeding is another low cost and low-technology carcass disposal option, however palatability must be properly maintained in order to minimize biosecurity concerns [92]. Disposal of carcasses by scavengers and ocean disposal may be categorized as obsolete mortality management options that are not recommended due to a number of environmental, health and social impacts.

Issues from other disposal technologies Proper carcass disposal technologies can effectively reduce the infectious hazards of mortality waste and prevent scavenging. However, these disposal methods still give rise to other health and environmental hazards. For example, significant amounts of contaminants such as ammonium-nitrogen (190-1400 mg L $\left.{ }^{-1}\right)$, TOC $\left(1000-10,000 \mathrm{mg} \mathrm{L}^{-1}\right)$, and total solid (5000-30,000 $\mathrm{mg} \mathrm{L}^{-1}$ ) have been found in leachate beneath carcass composting units [93] and these contaminants may affect soils and groundwater. Rendering can emit gases and odors, harming the aesthetic value of the environment if not eliminated by properly operated scrubbers [93, 94]. Insufficient pathogenic deactivation during composting may pose a risk to surrounding biodiversity and public health [87]. None of the available disposal techniques are $100 \%$ effective in treating carcasses, and all are associated with the risks of soil, water, and air contamination. Hence, a remediation plan should be mandated for all carcass disposal methods.

\section{Remediation measures Soil treatment}

To date, techniques such as excavation, washing, soil replacement, biodegradation or bioremediation, phytoremediation, advanced oxidation, and soil vapor extraction, have been applied to remediate sites contaminated with both organic and inorganic pollutants; carcass disposal sites would be no exception [95-98]. Excavation, soil replacement, and soil washing are used when immediate treatment action is required [99]. However, these techniques are often costly, require human resources, and allow for environmental contaminant exposure [100].

The intensification of natural biological degradation processes (i.e., biodegradation or bioremediation) may be preferred as a cost-effective method of removing contaminants from soil environments. Though inorganic compounds are not biodegradable, they can be bio-transformed so that resulting compounds are less toxic or less mobile. Bioremediation relies on proper environmental conditions such as $\mathrm{pH}$, temperature, oxygen, nutrients, and soil moisture [101].

Phytoremediation of contaminants using hyperaccumulator plants is another option for carcass disposal sites. During phytoremediation, plants are used to increase the degradation of organic contaminants, in concert with root rhizosphere microorganisms [97]. Phytoremediation of dredge sediments in landfills can be up to $79 \%$ effective in reduction of organic contaminants, mineral oils and polyaromatic hydrocarbons [102]. Plants such as C. arietinum and Vetiver show promise for absorbing antibiotics, and thus may have the potential to remediate antibioticcontaminated carcass disposal sites [96, 97]. However, phytoremediation effectiveness depends on the disposal site contaminant, the environment, and the plant species.

Some advanced techniques, such as oxidation processes, are relatively expensive, and by-products generated during oxidation may be more resistant to degradation [103]. Soil vapor extraction is an accepted method for the remediation of volatile organic compounds in soils. This cost-effective method allows for biodegradation to fewer volatile compounds through increased airflow. Unfortunately, soil vapor extraction is not appropriate for contaminated sites with shallow water tables $(<0.9 \mathrm{~m}$ from the surface) due to occurrence of upwelling that inhibits soil vapor flow [104].

\section{Water treatment}

When water contamination occurs due to carcass disposal issues, satisfactory treatment is not an easy task. Water contamination typically occurs due to the presence of organic pollutants, nutrients, and toxic compounds, as well as pathogenic microorganisms. The remediation technology choice depends largely on contaminated water characteristics, discharge limitations, and site constraints. Suggested clean-up methodologies include the use of chemicals, advanced oxidative processes, biological approaches, use of wetlands, emerging technologies, and adsorbents.

Alkaline chemicals (e.g., lime) can be used to inactivate pathogenic microorganisms in contaminated water. Disadvantages of this approach are potentially large odor and ammonia emissions, high cost, and further toxic environmental effects [105]. A number of advanced oxidation processes, including photocatalysis, Fenton, photo-Fenton, and dielectric barrier discharge plasma systems, have been suggested as viable options to remove aqueous contaminants such as pharmaceuticals [106109]. These techniques are highlighted as energy efficient, 
Table 3 Biochar utilization for environmental contaminant removal

\begin{tabular}{|c|c|c|c|c|c|c|}
\hline Pollutant & Media/conditions & Removal capacity & $\begin{array}{l}\text { Partition } \\
\text { coefficient }\end{array}$ & Type of biochar & $\begin{array}{l}\text { Production } \\
\text { conditions }\end{array}$ & Reference \\
\hline COD & $\begin{array}{l}\text { water/laboratory } \\
\text { conditions }\end{array}$ & $\sim 70 \mathrm{mg} \mathrm{g}^{-1}$ & $\sim 0.058 \mathrm{~L} \mathrm{~g}^{-1}$ & $\begin{array}{l}\text { Wood derived } \\
\text { biochar }\end{array}$ & $1000^{\circ} \mathrm{C}$ & [160] \\
\hline \multirow[t]{10}{*}{ Ammonium nitrogen } & $\begin{array}{l}\text { water/laboratory } \\
\text { conditions }\end{array}$ & $3.4 \mathrm{mg} \mathrm{g}^{-1}$ & $0.017 \mathrm{Lg}^{-1}$ & $\begin{array}{l}\text { Rice husk biochar } \\
\text { Cacao shell and corn } \\
\text { biochar }\end{array}$ & $\begin{array}{l}700^{\circ} \mathrm{C} \\
300-350^{\circ} \mathrm{C}\end{array}$ & {$[161,162]$} \\
\hline & & $44.64 \pm 0.602 \mathrm{mg} \mathrm{g}^{-1}$ & $0.032 \mathrm{~L} \mathrm{~g}^{-1}$ & Wood biochar & $600^{\circ} \mathrm{C}$ & [21] \\
\hline & & $39.8 \pm 0.540 \mathrm{mg} \mathrm{g}^{-1}$ & $0.028 \mathrm{~L} \mathrm{~g}^{-1}$ & Rice husk biochar & $600^{\circ} \mathrm{C}$ & [21] \\
\hline & & $0.753 \mathrm{mg} \mathrm{g}^{-1}$ & $0.025 \mathrm{Lg}^{-1}$ & Corn straw biochar & $<700^{\circ} \mathrm{C}$ & [163] \\
\hline & & $1.003 \mathrm{mg} \mathrm{g}^{-1}$ & $0.033 \mathrm{Lg}^{-1}$ & Peanut shell biochar & $<700^{\circ} \mathrm{C}$ & [163] \\
\hline & & $5.3 \mathrm{mg} \mathrm{g}^{-1}$ & $0.007 \mathrm{~L} \mathrm{~g}^{-1}$ & $\begin{array}{l}\text { Mixed hardwood } \\
\text { biochar }\end{array}$ & $300^{\circ} \mathrm{C}$ & [164] \\
\hline & & $17.6 \mathrm{mg} \mathrm{g}^{-1}$ & $0.074 \mathrm{Lg}^{-1}$ & $\begin{array}{l}\text { Plant (Thaliadealbata) } \\
\text { biomass derived } \\
\text { biochar }\end{array}$ & $700^{\circ} \mathrm{C}$ & [165] \\
\hline & & $5.6 \mathrm{mg} \mathrm{g}^{-1}$ & $0.062 \mathrm{Lg}^{-1}$ & $\begin{array}{l}\text { Pineapple peel } \\
\text { biochar }\end{array}$ & $300^{\circ} \mathrm{C}$ & [166] \\
\hline & & $4.71 \mathrm{mg} \mathrm{g}^{-1}$ & $0.069 \mathrm{Lg}^{-1}$ & Orange peel biochar & $300^{\circ} \mathrm{C}$ & [166] \\
\hline & & $2.65 \mathrm{mg} \mathrm{g}^{-1}$ & $0.034 \mathrm{Lg}^{-1}$ & Pitaya peel biochar & $400^{\circ} \mathrm{C}$ & [166] \\
\hline \multicolumn{7}{|l|}{ Antibiotics } \\
\hline Tylosin & $\begin{array}{l}\text { Soil/laboratory } \\
\text { conditions }\end{array}$ & - & - & $\begin{array}{l}\text { Pulpgrade hardwood } \\
\text { and softwood chips } \\
\text { biochar }\end{array}$ & 850 and $900{ }^{\circ} \mathrm{C}$ & [167] \\
\hline \multirow[t]{2}{*}{ Sulfamethazine } & $\begin{array}{l}\text { Water/laboratory } \\
\text { conditions }\end{array}$ & $33.81 \mathrm{mg} \mathrm{g}^{-1}$ & $1.738 \mathrm{Lg}^{-1}$ & Tea waste biochar & $\begin{array}{l}700^{\circ} \mathrm{C} \\
\text { Steam activated }\end{array}$ & [135] \\
\hline & $\begin{array}{l}\text { Water/laboratory } \\
\text { conditions }\end{array}$ & $37.7 \mathrm{mg} \mathrm{g}^{-1}$ & $1.809 \mathrm{Lg}^{-1}$ & $\begin{array}{l}\text { Invasive plant } \\
\text { biochar }\end{array}$ & $\begin{array}{l}700{ }^{\circ} \mathrm{C} \\
\text { Steam activated }\end{array}$ & [168] \\
\hline \multirow[t]{5}{*}{ Tetracycline } & $\begin{array}{l}\text { Water/laboratory } \\
\text { conditions }\end{array}$ & $14.3 \mathrm{mg} \mathrm{g}^{-1}$ & $0.152 \mathrm{Lg}^{-1}$ & Rice husk biochar & $450-500^{\circ} \mathrm{C}$ & [169] \\
\hline & $\begin{array}{l}\text { Water/laboratory } \\
\text { conditions }\end{array}$ & $101 \mathrm{mg} \mathrm{g}^{-1}$ & $3.061 \mathrm{Lg}^{-1}$ & $\begin{array}{l}\text { Pinewood sawdust } \\
\text { biochar }\end{array}$ & $\begin{array}{l}700{ }^{\circ} \mathrm{C} \\
\text { Pyrolyzed with 1:5, } \\
\text { air to } \mathrm{NO}_{2}\end{array}$ & [170] \\
\hline & $\begin{array}{l}\text { Water/laboratory } \\
\text { conditions }\end{array}$ & $2.5 \mathrm{mg} \mathrm{g}^{-1}$ & $0.138 \mathrm{Lg}^{-1}$ & $\begin{array}{l}\text { Bamboo sawdust } \\
\text { biochar }\end{array}$ & $300^{\circ} \mathrm{C}$ & [171] \\
\hline & $\begin{array}{l}\text { Water/laboratory } \\
\text { conditions }\end{array}$ & $4.4 \mathrm{mg} \mathrm{g}^{-1}$ & $0.267 \mathrm{Lg}^{-1}$ & $\begin{array}{l}\text { Bamboo sawdust } \\
\text { biochar }\end{array}$ & $450^{\circ} \mathrm{C}$ & [171] \\
\hline & $\begin{array}{l}\text { Water/laboratory } \\
\text { conditions }\end{array}$ & $147.9 \mathrm{mg} \mathrm{g}^{-1}$ & $1.623 \mathrm{Lg}^{-1}$ & $\begin{array}{l}\text { Spirulina sp. (microal- } \\
\text { gae) biochar }\end{array}$ & $750^{\circ} \mathrm{C}$ & [172] \\
\hline Sulfamethoxazole & $\begin{array}{l}\text { Real wastewater } \\
\text { solution }\end{array}$ & $27.7 \mathrm{mg} \mathrm{g}^{-1}$ & $2.815 \mathrm{~L} \mathrm{~g}^{-1}$ & $\begin{array}{l}\text { Ball milled hickory } \\
\text { chips biochar }\end{array}$ & $450^{\circ} \mathrm{C}$ & [173] \\
\hline Sulfadiazine & $\begin{array}{l}\text { Water/laboratory } \\
\text { conditions }\end{array}$ & $123.0 \mathrm{mg} \mathrm{g}^{-1}$ & $4.415 \mathrm{Lg}^{-1}$ & $\begin{array}{l}\text { Pinewood sawdust } \\
\text { biochar }\end{array}$ & $\begin{array}{l}700{ }^{\circ} \mathrm{C} \\
\text { Pyrolyzed with 1:5, } \\
\text { air to } \mathrm{NO}_{2}\end{array}$ & [170] \\
\hline Sulfapyridine & $\begin{array}{l}\text { Real wastewater } \\
\text { solution }\end{array}$ & $58.6 \mathrm{mg} \mathrm{g}^{-1}$ & $7.600 \mathrm{Lg}^{-1}$ & $\begin{array}{l}\text { Ball milled hickory } \\
\text { chips biochar }\end{array}$ & $450^{\circ} \mathrm{C}$ & [173] \\
\hline \multicolumn{7}{|l|}{ Hormones } \\
\hline Estrone & $\begin{array}{l}\text { Soil/laboratory } \\
\text { conditions }\end{array}$ & $0.035 \mathrm{mg} \mathrm{g}^{-1}$ & $0.097 \mathrm{~L} \mathrm{~g}^{-1}$ & $\begin{array}{l}\text { Pine saw dust } \\
\text { biochar }\end{array}$ & $\begin{array}{l}700^{\circ} \mathrm{C} \\
\text { Steam activated }\end{array}$ & [136] \\
\hline Oestradiol & $\begin{array}{l}\text { Soil/laboratory } \\
\text { conditions }\end{array}$ & $0.026 \mathrm{mg} \mathrm{g}^{-1}$ & $0.041 \mathrm{Lg}^{-1}$ & $\begin{array}{l}\text { Pine saw dust } \\
\text { biochar }\end{array}$ & $\begin{array}{l}700{ }^{\circ} \mathrm{C} \\
\text { Steam activated }\end{array}$ & [136] \\
\hline $\begin{array}{l}\text { Greenhouse Gases } \\
\text { Methane }\end{array}$ & & $\begin{array}{l}0.05-0.9 \mathrm{~mol} \mathrm{~kg}^{-1} \\
-\end{array}$ & $\begin{array}{l}- \\
-\end{array}$ & $\begin{array}{l}\text { Wood biochar } \\
\text { Wheat straw biochar }\end{array}$ & $\begin{array}{l}350-600^{\circ} \mathrm{C} \\
350-550^{\circ} \mathrm{C}\end{array}$ & {$[174,175]$} \\
\hline \multirow[t]{2}{*}{ Carbon dioxide } & - & - & - & Wheat straw biochar & $350-550^{\circ} \mathrm{C}$ & [175] \\
\hline & - & - & - & $\begin{array}{l}\text { Mixed sawdust } \\
\text { biochar }\end{array}$ & $500^{\circ} \mathrm{C}$ & [176] \\
\hline Nitrous oxide & - & - & - & Rice husk biochar & $450^{\circ} \mathrm{C}$ & [177] \\
\hline
\end{tabular}


Table 3 (continued)

\begin{tabular}{|c|c|c|c|c|c|c|}
\hline Pollutant & Media/conditions & Removal capacity & $\begin{array}{l}\text { Partition } \\
\text { coefficient }\end{array}$ & Type of biochar & $\begin{array}{l}\text { Production } \\
\text { conditions }\end{array}$ & Reference \\
\hline & - & - & - & Hardwood & $450-500^{\circ} \mathrm{C}$ & [178] \\
\hline & $\begin{array}{l}\text { Soil/laboratory } \\
\text { conditions }\end{array}$ & - & - & Pine sawdust biochar & 300 and $550^{\circ} \mathrm{C}$ & [179] \\
\hline \multicolumn{7}{|c|}{ Volatile organic compounds (VOCs) } \\
\hline Benzene & $\begin{array}{l}\text { Laboratory condi- } \\
\text { tions }\end{array}$ & $54.6 \mathrm{mg} \mathrm{g}^{-1}$ & - & Neem biochar & $550^{\circ} \mathrm{C}$ & [180] \\
\hline Toluene & $\begin{array}{l}\text { Laboratory condi- } \\
\text { tions }\end{array}$ & $65.5 \mathrm{mg} \mathrm{g}^{-1}$ & - & Neem biochar & $550^{\circ} \mathrm{C}$ & [180] \\
\hline Methyl chloride & $\begin{array}{l}\text { Laboratory condi- } \\
\text { tions }\end{array}$ & $39.6 \mathrm{mg} \mathrm{g}^{-1}$ & - & Neem biochar & $550^{\circ} \mathrm{C}$ & [180] \\
\hline Xylene & $\begin{array}{l}\text { Laboratory condi- } \\
\text { tions }\end{array}$ & $60.2 \mathrm{mg} \mathrm{g}^{-1}$ & - & Neem biochar & $550^{\circ} \mathrm{C}$ & [180] \\
\hline Chloroform & $\begin{array}{l}\text { Laboratory condi- } \\
\text { tions }\end{array}$ & $30.8 \mathrm{mg} \mathrm{g}^{-1}$ & - & Neem biochar & $550^{\circ} \mathrm{C}$ & [180] \\
\hline $\begin{array}{l}\text { Carbon tetrachlo- } \\
\text { ride }\end{array}$ & $\begin{array}{l}\text { Laboratory condi- } \\
\text { tions }\end{array}$ & $41.0 \mathrm{mg} \mathrm{g}^{-1}$ & - & Neem biochar & $550^{\circ} \mathrm{C}$ & [180] \\
\hline
\end{tabular}

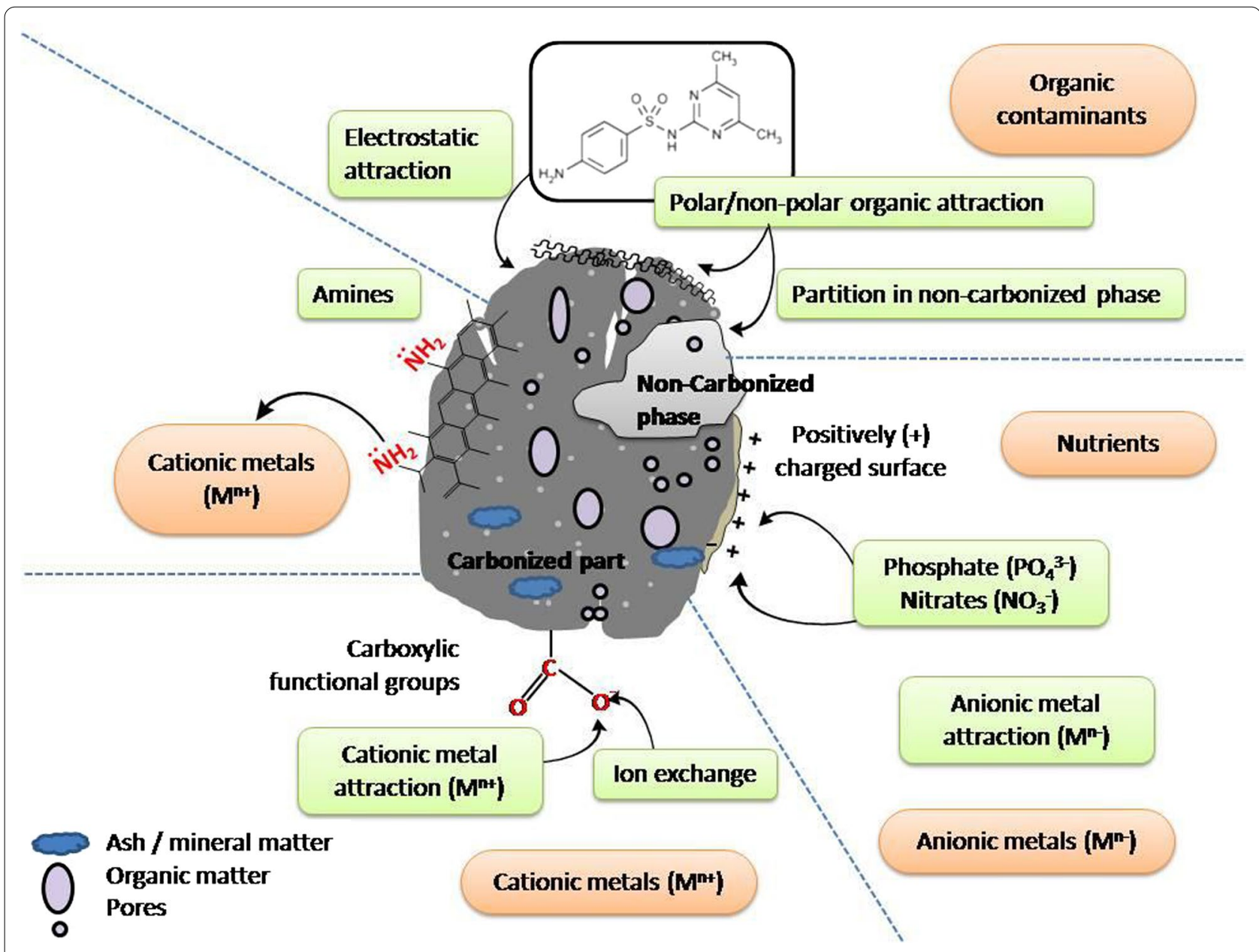

Fig. 1 Mechanisms involved in remediating contaminants from carcass disposal sites 
cost-effective, and environmentally friendly processes that can be used in large-scale water treatment [109].

Among the biological methods, aerobic processes are commonly used for organically-contaminated water treatment due to its relatively high efficiency [110]. Anaerobic treatment is another remediation option for fully-degradable substances in carcass-contaminated waters [111]. Moreover, anaerobic techniques have been proven to significantly reduce COD and BOD in contaminated waters [112]. In addition, constructed wetlands are land-based water treatment systems designed for treating wastewaters and contaminated waters [113]. They have been widely employed for livestock wastewater treatments because they are compatible with typical farm and ranch operations. Further, they are mostly effective in reducing micro contaminant concentrations, including antibiotics residues [114, 115]. Alvarez et al. [116] used choline dihydrogen phosphate (ChDHP), a biocompatible ionic liquid, to treat swine wastewater streams. This emerging technology has been proven, promising option for swine effluent antibiotic removal [116]. The above approaches may have some potential use for contaminated water remediation resulting from animal carcass and human corpse disposal sites.

Adsorption as a remediation tool is a fast, inexpensive, simple, and universal method, compared to other physical treatment technologies (e.g., sedimentation, flotation, ion exchange, and reverse osmosis). Adsorption efficiency largely depends on the adsorbent used. Water solution chemistry also plays an important role in the remediation/adsorption process [117]. Adsorbents, such as clay minerals [118], biomaterials [119], and zeolites [120] have been widely used to adsorb ions and organics in contaminated water. Activated carbons are also common and widely used adsorbents for the removal of inorganic and organic impurities, as well as undesirable odor and color, in wastewater. The adsorption capacity of activated carbon is attributed to its large surface area, microporous structure, variable surface characteristics, and high degree of surface reactivity [121]. Activated carbon has also been successfully used for the remediation of refractory organic compounds like tetracycline and sulfamethoxazole, which may persist in carcass leachate [122]. However, high production and operation costs, regeneration issues, and difficulty in operation are the potential drawbacks of using activated carbon for contaminant adsorption. Other means of adsorption via alternative carbon sources, could be an attractive means for carcass disposal reclamation scenarios.

\section{Biochar for managing mass carcass and corpse disposal sites}

In the search for suitable absorbent alternatives, many researchers have demonstrated that biochar is economically attractive, and may act similar to or even outperform activated carbon [123]. Biochar is the thermal degradation product of various materials or carbonbased products that otherwise would go to waste. Thus, biochar technology can enhance the environmental value of waste by reducing disposal cost and potentially improving sustainability via use in reclamation efforts. Biochar may be used for removing both soil and water contaminants due to the presence of oxygenated functional groups, increased cation exchange capacity, large surface area, high porosity, and the presence of oxides, hydroxides, and carbonate phases [124-127].

\section{Biochar as a sorbent}

The specific sorption properties of biochar for various contaminants may largely depend on the pyrolysis temperature, residence time, and feedstock type. Despite the ability to adsorb aqueous and soil phase contaminants, biochar application has shown the potential for reducing various organic and inorganic compounds in soil, as well as being effective in reducing greenhouse gas emissions [128]. Table 3 summarizes the use of biochar, derived from different feedstock materials under different pyrolysis conditions, for the remediation of aqueous, soil, and gaseous phase contaminants.

Biochar may reduce a variety of mobile organic and inorganic contaminants present in soils. Several mechanisms have been suggested for different contaminant remediation by biochar for anionic metals, cationic metals, and organics (Fig. 1). Several recent studies have revealed that biochar derived from rice husk could significantly adsorb ammonium-nitrogen and phosphate [129, 130]. Ammonium-nitrogen adsorption capacity of rice husk biochar was found to increase with decreasing biochar particle size [21]. It has been suggested that smaller sized biochar particles may lead to decrease hydraulic conductivity, extend the contact time with pollutants, and thereby enhanced remediation efficiency [21, 131].

Anionic metals/metalloids may be complexed with positively charged sites on biochar surfaces, depending on $\mathrm{pH}$ and $\mathrm{pH}$ at the zero point charge of the media [132]. At the same time, cationic metals in carcass leachate may be removed by various mechanisms such as ion exchange, surface complexation, precipitation (as oxides, hydroxides or carbonates), and reaction with amines on biochar surfaces (Fig. 1). In terms of organic contaminants, $\pi-\pi$ electron donor-acceptor interaction, polar and nonpolar interactions, electrostatic attraction, and partition into 


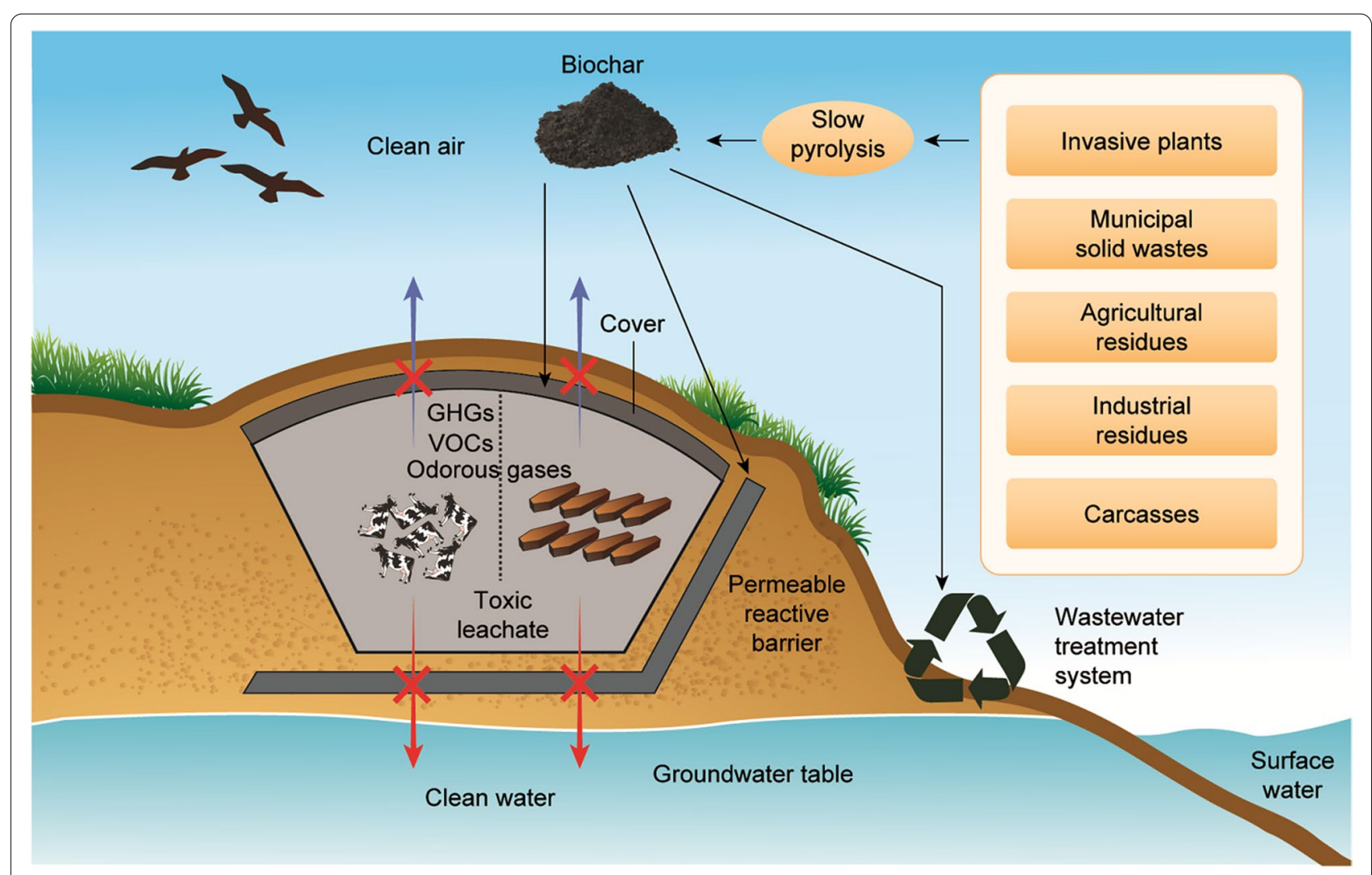

Fig. 2 Various applications of biochar in mass burial sites

the non-carbonized biochar phase have been reported $[124,133,134]$. Moreover, organic contaminants can be remediated through pore diffusion and adsorption on interior biochar surfaces. Sulfonamide, a veterinary pharmaceutical which may enter the environment through carcass burial site leachate, has been effectively remediated by using steam activated tea waste biochar [135]. The sorption mechanism was explained by physical surface area and pore volume changes that occurred during steam activation, which enhanced sulfonamide diffusion into biochar pores. Similarly, steam gasified pine sawdust biochar showed a high sorption capacity for steroid hormones (oestradiol and estrone), which may be added to soil through livestock faeces and urine deposition [136]. The authors highlighted that biochar created at a relatively high temperature $\left(700^{\circ} \mathrm{C}\right)$ had the appropriate surface area, low ash content and abundant polar functional groups that resulted in a high hormone sorption capacity as compared to lower temperature biochars. Sorption of the antibiotic lincomycin (widely used to control diseases in pigs, dairy cattle and sheep) was examined using manure derived biochar [137]. Relatively quick antibiotic sorption was explained by non-electrostatic interactions including hydrophobic partitioning, $\pi-\pi$ electron donor-acceptor interactions, and hydrogen and van der Waals bonding. In addition, biochar macro- and nanoporous structures contributed to long-term lincomycin sorption via slow diffusion into biochar pores. Results implied that biochar could be used as a long-term strategy for antibiotic immobilization in agroecosystems, and likely could be used at carcass disposal sites [137]. Rice husk biochar, modified by methanol, has been shown to sorb tetracycline (a common veterinary drug) [70]. Biochar functional group alteration, due to methanol modification, resulted in the formation of hydrogen bonds between contaminant molecules and biochar, likely leading to enhanced sorption. Biochar use for contaminant sorption and immobilization may be successfully incorporated into an in-situ remediation technology for groundwater, known as permeable reactive barriers 


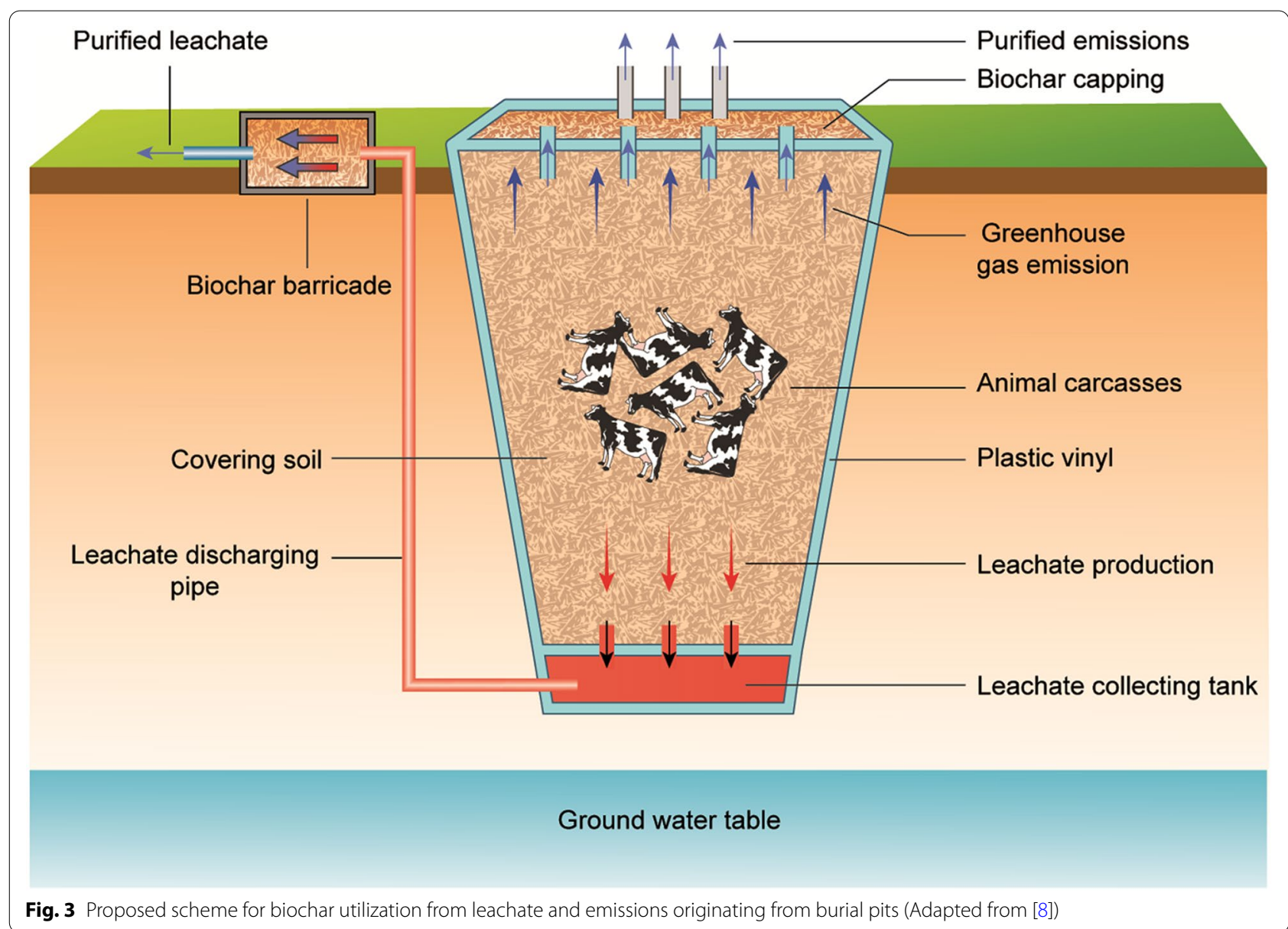

(PRBs) (96). Kim et al. [129] introduced a PRB containing rice husk biochar for ground/surface water contaminated with swine leachate [129]. Biochar effectively removed ammonium-nitrogen and potassium compared to phosphate, due to its high affinity for positively charged contaminants. The authors concluded that biochar derived from $\mathrm{MgCl}_{2}$ or $\mathrm{ZnCl}_{2}$ enriched feedstock, or modified base-enriched biochar, could be used to remediate both positively and negatively charged contaminants. Yoon et al. [19] also investigated rice husk biochar use in PRB to mitigate groundwater pollution from a pig carcass burial site, finding that leachate $\mathrm{pH}, \mathrm{EC}$, and ammonium-nitrogen were reduced by biochar application as compared to pre-treatment. Biochar also has use as a potential filtering agent for pathogenic organism removal from carcass/corpse leachate or from affected groundwater. Sasidharan et al. [138] demonstrated relatively high bacteria retention in biochar-amended sand columns. A similar study by Kranner et al. [139] found improved removal of the faecal indicator bacteria Escherichia coli, enterococci, and male-specific coliphage by biofilters amended with biochar as compared to sand biofilters alone. Thus, in situ biochar application to carcass/corpse contaminated sites may likely be a sustainable strategy for remediation (Fig. 2).

\section{Carcass derived biochar}

Pyrolytic conversion of carcasses into biochar has been considered an environmentally friendly and economical approach for carcass management [140]. This technique involves less emissions as compared to other management options, while the resulting biochar is considered a potential pollutant sorption material or an effective soil conditioner (Fig. 3). Betts et al. [141] emphasized this contention, noting that meat and bone meal derived biochar had a relatively high sorptive capacity for aqueous 
Zn. Lei et al. [142] utilized cattle carcass derived biochar to effectively sorb aqueous $\mathrm{Cd}$. Furthermore, the oil produced during carcass pyrolysis may be utilized as a raw material for bio-diesel production [143].

\section{Carcass-derived biochar as a soil amendment}

Animal waste has historically been the primary source of plant nutrients and as an amendment for agricultural crop production. Nevertheless, carcass waste used directly as a soil amendment may lead to disease dispersion risk. Thus, converting carcass waste into biochar via pyrolysis may be a sustainable management option, since heat treatment below typical pyrolysis temperatures (e.g., $500{ }^{\circ} \mathrm{C}$ ) has proven to be effective at killing associated pathogenic organisms [144]. Animal carcass biochar may provide essential plant nutrients for crop growth. Animal carcass by-products may contain up to $30 \%$ $\mathrm{P}_{2} \mathrm{O}_{5}$, which may make it an excellent $\mathrm{P}$ source. In support of this concept, Ma and Matsunaka [145] reported that dairy cattle carcass-derived biochar was an effective P fertilizer under acidic soil conditions. Several authors have reported that animal-origin biochar can be enriched in both $\mathrm{P}$ and $\mathrm{N}[146,147]$. A recent study compared pig carcass- to wood-derived biochar (Platanus orientalis) for nutrient bioavailability, enzymatic activity, and plant growth performance in soil contaminated with metalphthalic acid ester; results proved that carcass-derived biochar increased soil $\mathrm{P}$ and $\mathrm{K}$ availability, urease and acid phosphatase activities, and pak choi yield as compared to wood-derived biochar [148]. Favorable carcassderived biochar properties include alkaline $\mathrm{pH}$, elevated cation exchange capacity and nutrient content, all of which could benefit soils that either lack nutrients or the ability to retain nutrients. Carcass-derived biochars may also act like other biochars used as a soil amendment. Biochar land application can enhance water infiltration, water holding capacity, soil structural stability, and soil biological activity. It is yet to be seen if carcass-derived biochars will act similar once applied to soils, and therefore carcass-derived biochars should be further evaluated under field conditions.

\section{Future Perspectives}

This review article provides a detailed overview of carcass and corpse disposal techniques, their environmental impacts, and potential remediation strategies. Managing routine or catastrophic mortality is multifaceted, and depends on the cause of death, type, and quantity of animal carcasses or human corpses, as well on location and economic status. The true challenge involves selecting cost-effective and efficient technologies that protect public health and safety, avoid adverse water and air quality effects, and prevent the spread of disease.
Existing techniques used for carcass/corpse disposal include burying, burning, incineration, composting, rendering, and alkaline hydrolysis. Each treatment strategy has both benefits and disadvantages. Burial is the most common carcass and corpse disposal method; however, it can lead to soil and groundwater pollution. During disease outbreak events, burning and incineration are preferred, yet incineration can be costly due to the fuel and operational requirements. Rendering is an emerging technology which converts animal tissues into animal fat or protein for agricultural or industrial use. However, it remains unclear how to properly monitor and control the conditions during rendering in order to maintain biosecurity and reduce disease transmission. Alkaline hydrolysis, is in limited use due to high initial and operational costs, however this process has the potential for completely destroying infectious agents by solubilization and digestion. Other potential methods for carcass management are anaerobic digestion, fermentation, and dry extrusion, although their effectiveness has not been completely proven.

Although the existing literature focuses on the environmental impacts of carcass waste, there is limited research on remediation. Surface- and ground-water or soil contamination issues are frequently related to carcass disposal; evidence of elevated BOD, COD, TDS, ammonia-nitrogen, antibiotics, and steroid hormones from carcass disposal exist and should be addressed. Many conventional remediation methods are costly and ineffective for large-scale applications. However, adsorption techniques are generally effective and simple, and there is a wide scope of research on the adsorptive removal of organic and inorganic pollutants.

However, research to date has not focused on the treatment of complex carcass leachate; instead, the adsorption of single pollutants has been studied. Furthermore, growing research focus has been directed at finding acceptable, low cost, and efficient alternatives to conventionally utilized activated carbon. Carcass/corpse sites and wastewater remediation using biochar remains a completely unexplored area of study. While previous research has demonstrated that biochar is effective at removing BOD, COD, TDS, nutrients, and refractory chemicals like antibiotics in the environment, it is yet to be evaluated or proven effective in the presence of real-world carcass leachates.

In addition to the effectiveness of biochar at removing a multitude of constituents, it is also promising as a sorbent for methane and other greenhouse gases. Thus, biochar could potentially be used as a bio-cover and might be a suitable material for PRBs. Figure 3 suggests the potential use of biochar in order to treat toxic leachates and gaseous emissions from burial pits. The same approach 
has broad applicability for minimizing adverse environmental effects following animal/human burial events. Furthermore, biochar derived from animal waste can be enriched in nutrients, leading to improved crop growth. Thus, biochar produced from animal carcasses may be a "win-win" as it can be used for pollutant remediation and serve as a tool to improve soil properties. Creating biochar from and within carcass disposal systems may be worth future investigation.

\begin{abstract}
Abbreviations
LSU: Livestock units; FMD: Foot-and-mouth disease; BOD: Biological oxygen demand; COD: Chemical oxygen demand; TOC: Total organic carbon; TDS: Total dissolved solids; PAH: Polycyclic aromatic hydrocarbons; ChDHP: Choline dihydrogen phosphate; PRBs: Permeable reactive barriers.
\end{abstract}

\section{Acknowledgements}

This work was carried out with the support of the Cooperative Research Program for Agriculture Science and Technology Development (Project No. PJ01475801) from Rural Development Administration, the Republic of Korea. This work was also supported by the National Research Foundation of Korea (NRF) grant funded by the Korea government(MSIT) (No. 2021R1A2C2011734). This research was supported by Basic Science Research Program through the National Research Foundation of Korea (NRF) funded by the Ministry of Education (NRF-2021R1A6A1A10045235).

\section{Authors' contributions}

MV, YSO: Conceptualization, Writing the first draft, SSM: Writing the first draft, VG: Data visualization, writing the first draft, AUR: Writing the first draft, MA: Reviewing and editing, AA, AU: Reviewing and editing, MIA-W: Reviewing and editing, JAl: Reviewing and editing, YSO: Reviewing and editing. All authors read and approved the final manuscript.

\section{Funding}

Not applicable.

\section{Availability of data and materials \\ Not applicable.}

\section{Declarations}

\section{Competing interests}

The authors declare that they have no competing interests.

\begin{abstract}
Author details
${ }^{1}$ Ecosphere Resilience Research Centre, Faculty of Applied Sciences, University of Sri Jayewardenepura, Nugegoda 10250, Sri Lanka. ${ }^{2}$ School of Agriculture, Food and Wine, University of Adelaide, Adelaide, Australia. ${ }^{3}$ Department of Environmental Sciences, Faculty of Biological Sciences, Quaid-i-Azam University, Islamabad 45320, Pakistan. ${ }^{4}$ Industrial Psychology, College of Education, King Saud University, Riyadh, Saudi Arabia. ${ }^{5}$ Soil Sciences Department, College of Food and Agricultural Sciences, King Saud University, Riyadh, Saudi Arabia. ${ }^{6}$ Department of Soil and Crop Sciences, Colorado State University, Fort Collins, CO, USA. ${ }^{7}$ Korea Biochar Research Center, APRU Sustainable Waste Management and Division of Environmental Science and Ecological Engineering, Korea University, Seoul 02841, South Korea.
\end{abstract}

Received: 28 September 2021 Accepted: 16 November 2021

Published online: 22 December 2021

\section{References}

1. Reid K (2019) 2004 Indian Ocean earthquake and tsunami: Facts, FAQs, and how to help, World Vision
2. Morgan OW, Sribanditmongkol P, Perera C, Sulasmi Y, Van Alphen D, Sondorp E (2006) Mass fatality management following the South Asian tsunami disaster: case studies in Thailand, Indonesia, and Sri Lanka. PLoS Med 3(6):e195-e195

3. Commission JFWCA and Organization WH (2007) Organically Produced Foods, Food \& Agriculture Org

4. Li X, Zhu N, Wang Y, Li P, Wu P, Wu J (2013) Animal carcass wastewater treatment and bioelectricity generation in up-flow tubular microbial fuel cells: effects of HRT and non-precious metallic catalyst. Biores Technol 128:454-460

5. Alexandratos N, Bruinsma J (2012) World agriculture towards 2030/2050: the 2012 revision, ESA Working paper Rome, FAO

6. He L, Fan S, Müller K, Wang H, Che L, Xu S, Song Z, Yuan G, Rinklebe J, Tsang DCW (2018) Comparative analysis biochar and compost-induced degradation of di-(2-ethylhexyl) phthalate in soils. Sci Total Environ 625:987-993

7. Knight-Jones T, Rushton J (2013) The economic impacts of foot and mouth disease - what are they, how big are they and where do they occur? Prev Vet Med 112(3):161-173

8. Koh EH, Kaown D, Kim HJ, Lee KK, Kim H, Park S (2019) Nationwide groundwater monitoring around infectious-disease-caused livestock mortality burials in Korea: superimposed influence of animal leachate on pre-existing anthropogenic pollution. Environ Int 129:376-388

9. Park JH, Lee KN, Ko YJ, Kim SM, Lee HS, Shin YK, Sohn HJ, Park JY, Yeh JY, Lee YH (2013) Control of foot-and-mouth disease during 2010-2011 epidemic. South Korea Emerg Infect Dis 19(4):655

10. Vergne T, Gogin A, Pfeiffer D (2015) Statistical exploration of local transmission routes for African swine fever in pigs in the Russian Federation, 2007-2014. Transbound Emerg Dis 64:504

11. Yoon H, Yhee J, Yu C, Kim J, Moon O, Park J, Nam G, Sur J, Rhee H, Kim $T$ (2009) Comparison of Process and cost of disposal methods for brucellosis infected bovine carcasses: burial, recycling, and incineration. Korean Journal of Veterinary Research

12. Sternberg $T$ (2010) Unravelling Mongolia's extreme winter disaster of 2010. Nomadic Peoples 14(1):72-86

13. Consortium NABSC (2004) Carcass disposal: a comprehensive review. Prepared by the National Agricultural Bio-security Center Consortium at Kansas State University, Carcass Disposal Working Group for the USDA Animal \& Plant Health Inspection Service per Cooperative Agreement, 02-1001

14. Gwyther CL, Williams AP, Golyshin PN, Edwards-Jones G, Jones DL (2011) The environmental and biosecurity characteristics of livestock carcass disposal methods: a review. Waste Manage 31(4):767-778

15. Hseu ZY, Chen ZS (2017) Experiences of mass pig carcass disposal related to groundwater quality monitoring in Taiwan. Sustainability $9(1): 46-51$

16. Domańska E (2019) The environmental history of mass graves. J Genocide Res $1-15$

17. Ucisik AS, Rushbrook P (1998) The impact of cemetaries on the environment and public health: an introductory briefing. WHO Regional Office for Europe, Copenhagen

18. Żychowski J, Bryndal T (2015) Impact of cemeteries on groundwater contamination by bacteria and viruses - a review. J Water Health 13(2):285-301

19. Yoon JH, Kim YN, Shin DC, Kim KR, Kim KH (2017) Management of animal carcass disposal sites using a biochar permeable reactive barrier and fast growth tree (Populus euramericana): a field study in Korea. Sustainability 9(3):457

20. Perez-Mercado LF, Lalander C, Joel A, Ottoson J, Dalahmeh S, Vinnerås $B$ (2019) Biochar filters as an on-farm treatment to reduce pathogens when irrigating with wastewater-polluted sources. J Environ Manage 248:109295

21. Kizito S, Wu S, Kirui WK, Lei M, Lu Q, Bah H, Dong R (2015) Evaluation of slow pyrolyzed wood and rice husks biochar for adsorption of ammonium nitrogen from piggery manure anaerobic digestate slurry. Sci Total Environ 505:102-112

22. Yin $Q$, Zhang B, Wang R, Zhao Z (2017) Biochar as an adsorbent for inorganic nitrogen and phosphorus removal from water: a review. Environ Sci Pollut Res 24(34):26297-26309

23. Ippolito J, Berry C, Strawn D, Novak J, Levine J, Harley A (2017) Biochars reduce mine land soil bioavailable metals. J Environ Qual 46:411-419 
24. De Rozari P, Greenway M, El Hanandeh A (2015) An investigation into the effectiveness of sand media amended with biochar to remove BOD5, suspended solids and coliforms using wetland mesocosms. Water Sci Technol 71(10):1536-1544

25. Kaetzl K, Lübken M, Nettmann E, Krimmler S, Wichern M (2020) Slow sand filtration of raw wastewater using biochar as an alternative filtration media. Sci Rep 10(1):1229

26. Peiris C, Gunatilake SR, Mlsna TE, Mohan D, Vithanage M (2017) Biochar based removal of antibiotic sulfonamides and tetracyclines in aquatic environments: a critical review. Biores Technol 246:150-159

27. Alizadeh S, Prasher SO, ElSayed E, Qi Z, Patel RM (2018) Effect of biochar on fate and transport of manure-borne estrogens in sandy soil. J Environ Sci 73:162-176

28. Grose DJ, Dolezal Jr HG (2004) Method and apparatus for tracking carcasses. Washington, D.U.S.P.a.T.O. (ed), Google Patents, United States

29. Kaczmarek B (2019) The heavy metal hazard of undiscovered World War I and II graves in Poland. Global NEST J 21(4):461-465

30. Tsokos M, Lessig R, Grundmann C, Benthaus S, Peschel O (2006) Experiences in tsunami victim identification. Int J Legal Med 120(3):185-187

31. Amuno AS (2013) Environmental legacy of the genocide: an exploration into the contamination potential of mass grave soils in post-genocide rwanda, University of Saint Joseph

32. Yuan Q, Snow DD, Bartelt-Hunt SL (2013) Potential water quality impacts originating from land burial of cattle carcasses. Sci Total Environ 456:246-253

33. Kim MH, Kim G (2017) Analysis of environmental impacts of burial sites. J Mater Cycles Waste Manage. 1-11

34. Ellis DB (2001) Carcass Disposal Issues in Recent Disasters, Accepted Methods, and Suggested Plan to Mitigate Future Events, Southwest Texas State University

35. Freedman R, Fleming R (2003) Water quality impacts of burying livestock mortalities. Livestock Mortality Recycling Project Steering Committee, Ridgetown, Ontario, Canada

36. Yuan Q, Saunders SE, Bartelt-Hunt SL (2012) Methane and carbon dioxide production from simulated anaerobic degradation of cattle carcasses. Waste Manage 32(5):939-943

37. Chowdhury S, Kim GH, Ok YS, Bolan N (2019) Effect of carbon and nitrogen mobilization from livestock mortalities on nitrogen dynamics in soil. Process Saf Environ Prot 122:153-160

38. Ritter W, Chirnside A (1995) Impact of dead bird disposal pits on ground-water quality on the Delmarva Peninsula. Biores Technol 53(2):105-111

39. Watkiss P, Smith A (2005) CBA of foot and mouth disease control strategies: environmental impacts. report for risk solutions, AEA Technology (Environment)

40. Salcedo DE, Kim S (2017) Fate of tetracycline resistance in synthetic livestock carcass leachate for two years. J Environ Manage 187:220-228

41. Kaown D, Kim H, Moon HS, Ko KS, Lee KK (2015) Hydrogeochemical and microbial characteristics in aquifers contaminated with leachate from animal carcass disposal sites. Environ Earth Sci 73(8):4647-4657

42. Macarthur AJ (2003) Leachate characteristics arising from the foot and mouth mass burial site In Scotland, Proceedings of the International Waste \& Landfill Symposium. http://www.leachate.co.uk/Foot_and Mouth_Disease_Leachate_Paper.pdf

43. Pratt DL (2009) Environmental impact of livestock mortalities burial

44. Hatzell HH (1995) Effects of waste-disposal practices on ground-water quality at five poultry (broiler) farms in north-central Florida, 1992-93, Citeseer

45. Joung HK, Han SH, Park SJ, Jheong WH, Ahn TS, Lee JB, Jeong YS, Jang KL, Lee GC, Rhee OJ (2013) Nationwide surveillance for pathogenic microorganisms in groundwater near carcass burials constructed in South Korea in 2010. Int J Environ Res Public Health 10(12):7126-7143

46. MacArthur A, Milne, J (2002) Leachate characteristics and management requirements arising from the foot \& mouth operations in Scotland. Proceedings Waste 2002 Integrated Waste Management and Pollution Control: Research, Policy, and Practice: 2002, 305-314

47. Glanville T (2000) Impact of livestock burial on shallow groundwater quality. Proc American Society of Agricultural Engineers

48. Charzyński P, Bednarek R, Śołnowska B (2010) Characteristics of the soils of Toruń cemeteries, pp. 13-16, International Union of Soil Sciences (IUSS), c/o Institut für Bodenforschug
49. Janaway RC, Percival SL, Wilson AS (2009) Microbiology and aging. Springer. pp. 313-334

50. Tibbett M, Carter DO (2008) Soil analysis in forensic taphonomy: chemical and biological effects of buried human remains. CRC Press

51. Wilson AS, Janaway RC, Holland AD, Dodson HI, Baran E, Pollard AM Tobin DJ (2007) Modelling the buried human body environment in upland climes using three contrasting field sites. Forensic Sci Int 169(1):6-18

52. Silva LM (1995) Os Cemitérios na Problemática Ambiental. [The cemeteries as an environmental issue], pp. 1-8, SINCESP \& ACEMBRA, Sao Paulo

53. Matos BA (2001) Avaliação da Ocorrência e do Transporte de Microrganismos no Aqüífero Freático do Cemitério de Vila

54. Amuno SA, Amuno MM (2014) Geochemical assessment of two excavated mass graves in Rwanda: a pilot study. Soil Sediment Contaminat Int J 23(2):144-165

55. Jonker C, Olivier J (2012) Mineral contamination from cemetery soils: case study of Zandfontein Cemetery, South Africa. Int J Environ Res Public Health 9(2):511-520

56. Spongberg AL, Becks PM (2000) Inorganic soil contamination from cemetery leachate. Water Air Soil Pollut 117(1-4):313-327

57. Morgan O (2004) Infectious disease risks from dead bodies following natural disasters. Rev Panam Salud Publica 15:307-312

58. Williams A, Temple T, Pollard SJ, Jones RJA, Ritz K (2009) Criminal and environmental soil forensics, pp. 87-101, Springer

59. Pacheco A (2000) Cemitérios e Meio Ambiente. [Cemeteries and Environment], Universidade de São Paulo

60. Nutsch A, Spire M (2004) Carcass disposal: a comprehensive review. Kansas State University, Manhattan, KS, National Agricultural Biosecurity Center

61. Abia ALK, Alisoltani A, Ubomba-Jaswa E, Dippenaar MA (2019) Microbial life beyond the grave: $16 \mathrm{~S}$ rRNA gene-based metagenomic analysis of bacteria diversity and their functional profiles in cemetery environments. Sci Total Environ 655:831-841

62. Wigginton KR, Ye Y, Ellenberg RM (2015) Emerging investigators series: the source and fate of pandemic viruses in the urban water cycle. Environ Sci Water Res Technol 1(6):735-746

63. Butterfield WK (1975) Reference Manual, Foreign Animal Disease Courses, Plum Island Animal Disease Center, ARS, USDA, USDA Press

64. Demirbas A (2011) Waste management, waste resource facilities and waste conversion processes. Energy Convers Manage 52(2):1280-1287

65. Chen SJ, Hsieh LT, Chiu SC (2003) Emission of polycyclic aromatic hydrocarbons from animal carcass incinerators. Sci Total Environ 313(1):61-76

66. Porteous A (2005) Why energy from waste incineration is an essential component of environmentally responsible waste management. Waste Manage 25(4):451-459

67. Croen LA, Shaw GM, Sanbonmatsu L, Selvin S, Buffler PA (1997) Maternal residential proximity to hazardous waste sites and risk for selected congenital malformations. Epidemiology 8:347-354

68. Staessen JA, Nawrot T, Den Hond E, Thijs L, Fagard R, Hoppenbrouwers K, Koppen G, Nelen V, Schoeters G, Vanderschueren D (2001) Renal function, cytogenetic measurements, and sexual development in adolescents in relation to environmental pollutants: a feasibility study of biomarkers. The Lancet 357(9269):1660-1669

69. Dummer T, Dickinson H, Parker L (2003) Adverse pregnancy outcomes around incinerators and crematoriums in Cumbria, north west England 1956-93. J Epidemiol Community Health 57(6):456-461

70. Abbasi S, Abbasi N (2000) The likely adverse environmental impacts of renewable energy sources. Appl Energy 65(1-4):121-144

71. Mari M, Domingo JL (2010) Toxic emissions from crematories: a review. Environ Int 36(1):131-137

72. Xue Y, Cheng L, Chen X, Zhai X, Wang W, Zhang W, Bai Y, Tian H, Nie L, Zhang S (2018) Emission characteristics of harmful air pollutants from cremators in Beijing, China. PLoS ONE 13(5):e0194226

73. Wang LC, Lee WJ, Lee WS, Chang-Chien GP, Tsai PJ (2003) Characterizing the emissions of polychlorinated dibenzo-p-dioxins and dibenzofurans from crematories and their impacts to the surrounding environment. Environ Sci Technol 37(1):62-67

74. Xiong C, Wang W, Li D, Yin L, Chen X, Xing X, Lu Q, Xiao C (2013) Characteristics of PCDD/DFs emission from crematories and their impacts to vicinity soil. Environ Sci Technol (China) 36(9):192-197 
75. Martin Jr J, Coombe J, Henn K (2012) Dairy Cattle Mortality Management via Anaerobic Digestion. GOT MANURE? , 86

76. Vandevivere P, De Baere L, Verstraete W (2003) Biomethanization of the organic fraction of municipal solid wastes, pp. 111-140, Iwa Publishing

77. Franke-Whittle IH, Insam H (2013) Treatment alternatives of slaughterhouse wastes, and their effect on the inactivation of different pathogens: a review. Crit Rev Microbiol 39(2):139-151

78. Maynaud G, Pourcher AM, Ziebal C, Cuny A, Druilhe C, Steyer JP, Wéry N (2016) Persistence and potential viable but non-culturable state of pathogenic bacteria during storage of digestates from agricultural biogas plants. Front Microbiol 7:1469

79. Yu H, Fang HH (2001) Inhibition by chromium and cadmium of anaerobic acidogenesis. Water Sci Technol 43(11):267-274

80. Sander JE, Warbington MC, Myers LM (2002) Selected methods of animal carcass disposal. J Am Vet Med Assoc 220(7):1003-1005

81. Gousterova A, Nustorova M, Christov P, Nedkov P, Neshev G, VasilevaTonkova E (2008) Development of a biotechnological procedure for treatment of animal wastes to obtain inexpensive biofertilizer. World J Microbiol Biotechnol 24(11):2647-2652

82. Kalambura S, Krička, T (2008) Alkaline hydrolysis of animal waste as pretreatment in production of fermented fertilizers, pp. 179-182, Akadémiai Kiadó

83. Pollard SJ, Hickman GA, Irving P, Hough RL, Gauntlett DM, Howson SF, Hart A, Gayford P, Gent N (2008) Exposure assessment of carcass disposal options in the event of a notifiable exotic animal disease: application to avian influenza virus. Environ Sci Technol 42(9):3145-3154

84. Saha N, Kharbuli ZY, Bhattacharjee A, Goswami C, Häussinger D (2002) Effect of alkalinity $(\mathrm{pH} 10)$ on ureogenesis in the air-breathing walking catfish, Clarias batrachus. Comp Biochem Physiol A Mol Integr Physiol 132(2):353-364

85. Mayes WM, Younger PL, Aumo J (2006) Buffering of alkaline steel slag leachate across a natural wetland. Environ Sci Technol 40(4):1237-1243

86. Gomes HI, Mayes WM, Rogerson M, Stewart DI, Burke IT (2016) Alkaline residues and the environment: a review of impacts, management practices and opportunities. J Clean Prod 112:3571-3582

87. Wilkinson KG (2007) The biosecurity of on-farm mortality composting. J Appl Microbiol 102(3):609-618

88. Akdeniz N, Koziel JA, Ahn HK, Glanville TD, Crawford BP, Raman DR (2010) Laboratory scale evaluation of volatile organic compound emissions as indication of swine carcass degradation inside biosecure composting units. Biores Technol 101(1):71-78

89. Zheng JL, Zhu MQ, Wu HT (2015) Alkaline hydrothermal liquefaction of swine carcasses to bio-oil. Waste Manage 43:230-238

90. Brandelli A, Sala L, Kalil SJ (2015) Microbial enzymes for bioconversion of poultry waste into added-value products. Food Res Int 73:3-12

91. Gupta R, Ramnani P (2006) Microbial keratinases and their prospective applications: an overview. Appl Microbiol Biotechnol 70(1):21

92. Morrow WM, Ferket PR (1993) The disposal of dead pigs: a review. Swine health and production: the official journal of the American Association of Swine Practitioners (USA)

93. Glanville TD, Richard TL, Harmon JD, Reynolds DL, Sadaka S, Akinc S (2003) Environmental Impact \& Biosecurity of Composting for Emergency Disposal of Livestock Mortalities, p. 1, American Society of Agricultural and Biological Engineers

94. Kim GH, Pramanik S (2015) Biosecurity procedures for the environmental management of carcasses burial sites in Korea. Environ Geochem Health 1-12

95. Beiyuan J, Tsang DCW, Yip ACK, Zhang W, Ok YS Li XD (2016) Risk mitigation by waste-based permeable reactive barriers for groundwater pollution control at e-waste recycling sites. Environ Geochem Health. $1-14$

96. Datta R, Das P, Smith S, Punamiya P, Ramanathan DM, Reddy R, Sarkar D (2013) Phytoremediation potential of vetiver grass [Chrysopogon zizanioides (L.)] for tetracycline. Int J Phytoremed 15(4):343-351

97. Makhijani M, Gahlawat S, Chauhan K, Valsangkar S, Gauba P (2014) Phytoremediation potential of Cicer arietinum for Tetracycline. Int J Genetic Eng Biotechnol 5(2):153-160

98. Rizwan M, Ali S, Rizvi H, Rinklebe J, Tsang DCW, Meers E, OkYS, Ishaque W (2016) Phytomanagement of heavy metals in contaminated soils using sunflower: a review. Crit Rev Environ Sci Technol 46(18):1498-1528
99. Tsang DCW, Yip ACK (2014) Comparing chemical-enhanced washing and waste-based stabilisation approach for soil remediation. J Soils Sediments 14(5):936-947

100. Riser-Roberts E (1998) Remediation of petroleum contaminated soils: biological, physical, and chemical processes. CRC Press

101. Hamby D (1996) Site remediation techniques supporting environmental restoration activities - a review. Sci Total Environ 191(3):203-224

102. Vervaeke P, Luyssaert S, Mertens J, Meers E, Tack F, Lust N (2003) Phytoremediation prospects of willow stands on contaminated sediment: a field trial. Environ Pollut 126(2):275-282

103. Mehrjouei M, Müller S, Möller D (2014) Energy consumption of three different advanced oxidation methods for water treatment: a costeffectiveness study. J Clean Prod 65:178-183

104. Khan Fl, Husain T, Hejazi R (2004) An overview and analysis of site remediation technologies. J Environ Manage 71(2):95-122

105. Mohaibes M, Heinonen-Tanski H (2004) Aerobic thermophilic treatment of farm slurry and food wastes. Biores Technol 95(3):245-254

106. Fan Y, Ji Y, Kong D, Lu J, Zhou Q (2015) Kinetic and mechanistic investigations of the degradation of sulfamethazine in heat-activated persulfate oxidation process. J Hazard Mater 300:39-47

107. Hussain S, Gul S, Steter JR, Miwa DW, Motheo AJ (2015) Route of electrochemical oxidation of the antibiotic sulfamethoxazole on a mixed oxide anode. Environ Sci Pollut Res 22:15004-15015

108. Mezyk SP, Neubauer TJ, Cooper WJ, Peller JR (2007) Free-radical-induced oxidative and reductive degradation of sulfa drugs in water: absolute kinetics and efficiencies of hydroxyl radical and hydrated electron reactions. J Phys Chem A 111(37):9019-9024

109. Parra KN, Gul S, Aquino JM, Miwa DW, Motheo AJ (2016) Electrochemical degradation of tetracycline in artificial urine medium. J Solid State Electrochem 20(4):1001-1009

110. Abeling U, Seyfried C (1992) Anaerobic-aerobic treatment of highstrength ammonium wastewater-nitrogen removal via nitrite. Water Sci Technol 26(5-6):1007-1015

111. Salminen E, Rintala J (2002) Anaerobic digestion of organic solid poultry slaughterhouse waste-a review. Biores Technol 83(1):13-26

112. Mittal GS (2006) Treatment of wastewater from abattoirs before land application—a review. Biores Technol 97(9):1119-1135

113. Vymazal J (2011) Constructed Wetlands for wastewater treatment: five decades of experience. Environ Sci Technol 45(1):61-69

114. Conkle JL, Lattao C, White JR, Cook RL (2010) Competitive sorption and desorption behavior for three fluoroquinolone antibiotics in a wastewater treatment wetland soil. Chemosphere 80(11):1353-1359

115. Liu L, Liu C, Zheng J, Huang X, Wang Z, Liu Y, Zhu G (2013) Elimination of veterinary antibiotics and antibiotic resistance genes from swine wastewater in the vertical flow constructed wetlands. Chemosphere 91(8):1088-1093

116. Álvarez M, Gómez L, Ulloa R, Deive F, Sanromán M, Rodríguez A (2016) Antibiotics in swine husbandry effluents: laying the foundations for their efficient removal with a biocompatible ionic liquid. Chem Eng 」 298:10-16

117. Yang Q, Chen G, Zhang J, Li H (2015) Adsorption of sulfamethazine by multi-walled carbon nanotubes: effects of aqueous solution chemistry. RSC Adv 5(32):25541-25549

118. Orthman J, Zhu H, Lu G (2003) Use of anion clay hydrotalcite to remove coloured organics from aqueous solutions. Sep Purif Technol 31(1):53-59

119. Crini G (2005) Recent developments in polysaccharide-based materials used as adsorbents in wastewater treatment. Prog Polym Sci 30(1):38-70

120. Hedström A (2001) lon exchange of ammonium in zeolites: a literature review. J Environ Eng 127(8):673-681

121. Dias JM, Alvim-Ferraz MC, Almeida MF, Rivera-Utrilla J, Sánchez-Polo M (2007) Waste materials for activated carbon preparation and its use in aqueous-phase treatment: a review. J Environ Manage 85(4):833-846

122. Vithanage M, Chandrajith R, Weerasooriya R (2009) Natural red earth as a material for arsenic removal in drinking water. Earth Science Frontier 1

123. Zheng W, Guo M, Chow T, Bennett DN, Rajagopalan N (2010) Sorption properties of greenwaste biochar for two triazine pesticides. J Hazard Mater 181(1-3):121-126 
124. Ahmad M, Rajapaksha AU, Lim JE, Zhang M, Bolan N, Mohan D, Vithanage M, Lee SS, OkYS (2014) Biochar as a sorbent for contaminant management in soil and water: a review. Chemosphere 99:19-33

125. Beesley L, Moreno-Jiménez E, Gomez-Eyles JL, Harris E, Robinson B, Sizmur T (2011) A review of biochars' potential role in the remediation, revegetation and restoration of contaminated soils. Environ Pollut 159(12):3269-3282

126. Ippolito JA, Berry CM, Strawn DG, Novak JM, Levine J, Harley A (2017) Biochars reduce mine land soil bioavailable metals. J Environ Qual 46(2):411-419

127. Mohan D, Sarswat A, Ok YS, Pittman CU (2014) Organic and inorganic contaminants removal from water with biochar, a renewable, low cost and sustainable adsorbent-a critical review. Biores Technol 160:191-202

128. Lehmann J, Joseph S (2015) Biochar for environmental management: science, technology and implementation. Routledge

129. Kim GH, Chowdhury S, Bolan N (2016) Assessing the efficiency of permeable reactive barrier to reduce the groundwater contamination from carcass burial, pp. 9-14

130. Yoon J, Kim K (2016) Application of biochar from organic wastes for remediation of leachate from animal carcass. Proceedings of the Korean Society of Soil Sciences and Fertilizer, Muju, Korea, 20-21

131. Wen D, Ho YS, Tang X (2006) Comparative sorption kinetic studies of ammonium onto zeolite. J Hazard Mater 133(1-3):252-256

132. Vithanage M, Rajapaksha AU, Ahmad M, Uchimiya M, Dou X, Alessi DS, Ok YS (2015) Mechanisms of antimony adsorption onto soybean stoverderived biochar in aqueous solutions. J Environ Manage 151:443-449

133. Vithanage M, Rajapaksha AU, Tang X, Thiele-Bruhn S, Kim KH, Lee SE, Ok YS (2014) Sorption and transport of sulfamethazine in agricultural soils amended with invasive-plant-derived biochar. J Environ Manage 141:95-103

134. Vithanage M, Rajapaksha AU, Zhang M, Thiele-Bruhn S, Lee SS, Ok YS (2015) Acid-activated biochar increased sulfamethazine retention in soils. Environ Sci Pollut Res 22(3):2175-2186

135. Rajapaksha AU, Vithanage M, Zhang M, Ahmad M, Mohan D, Chang SX, Ok YS (2014) Pyrolysis condition affected sulfamethazine sorption by tea waste biochars. Biores Technol 166:303-308

136. Sarmah AK, Srinivasan P, Smernik RJ, Manley-Harris M, Antal MJ, Downie A, van Zwieten $L$ (2010) Retention capacity of biochar-amended New Zealand dairy farm soil for an estrogenic steroid hormone and its primary metabolite. Soil Research 48(7):648-658

137. Liu CH, Chuang YH, Li H, Teppen BJ, Boyd SA, Gonzalez JM, Johnston CT, Lehmann J, Zhang W (2016) Sorption of lincomycin by manure-derived biochars from water. J Environ Qual 45(2):519-527

138. Sasidharan S, Torkzaban S, Bradford SA, Kookana R, Page D, Cook PG (2016) Transport and retention of bacteria and viruses in biocharamended sand. Sci Total Environ 548:100-109

139. Kranner BP, Afrooz ARMN, Fitzgerald NJM, Boehm AB (2019) Fecal indicator bacteria and virus removal in stormwater biofilters: effects of biochar, media saturation, and field conditioning. PLOS ONE 14(9):e0222719

140. Cascarosa E, Becker J, Ferrante L, Briens C, Berruti F, Arauzo J (2011) Pyrolysis of meat-meal and bone-meal blends in a mechanically fluidized reactor. J Anal Appl Pyrol 91(2):359-367

141. Betts AR, Chen N, Hamilton JG, Peak D (2013) Rates and mechanisms of $\mathrm{Zn}^{2+}$ adsorption on a meat and bonemeal biochar. Environ Sci Technol 47(24):14350-14357

142. Lei S, Zhu L, Xue C, Hong C, Wang J, Che L, Hu Y, Qiu Y (2020) Mechanistic insights and multiple characterizations of cadmium binding to animal-derived biochar. Environ Pollut 258:113675

143. Chaala A, Roy C (2003) Recycling of meat and bone meal animal feed by vacuum pyrolysis. Environ Sci Technol 37(19):4517-4522

144. Cascarosa E, Gea G, Arauzo J (2012) Thermochemical processing of meat and bone meal: a review. Renew Sustain Energy Rev 16(1):942-957

145. Ma YL, Matsunaka T (2013) Biochar derived from dairy cattle carcasses as an alternative source of phosphorus and amendment for soil acidity. Soil Sci Plant Nutr 59(4):628-641

146. Bridle T, Pritchard D (2004) Energy and nutrient recovery from sewage sludge via pyrolysis. Water Sci Technol 50(9):169-175
147. Chan K, Van Zwieten L, Meszaros I, Downie A, Joseph S (2008) Agronomic values of greenwaste biochar as a soil amendment. Soil Research 45(8):629-634

148. Chen H, Yang X, Wang H, Sarkar B, Shaheen SM, Gielen G, Bolan N, Guo J, Che L, Sun H (2020) Animal carcass-and wood-derived biochars improved nutrient bioavailability, enzyme activity, and plant growth in metal-phthalic acid ester co-contaminated soils: a trial for reclamation and improvement of degraded soils. J Environ Manage 261:110246

149. Yang P, Chu R, Chung W, Sung H (1998) Epidemiological characteristics and financial costs of the 1997 foot-and-mouth disease epidemic in Taiwan. Vet Rec 145(25):731-734

150. Harrison R (2014) Pollution 5th Edition: Causes, Effects and Control, Royal Society of Chemistry

151. Hayama Y, Kimura Y, Yamamoto T, Kobayashi S, Tsutsui T (2015) Potential risk associated with animal culling and disposal during the foot-andmouth disease epidemic in Japan in 2010. Res Vet Sci 102:228-230

152. Guan J, Chan M, Grenier C, Wilkie D, Brooks B, Spencer J (2009) Survival of avian influenza and Newcastle disease viruses in compost and at ambient temperatures based on virus isolation and real-time reverse transcriptase PCR. Avian Dis 53(1):26-33

153. Noakes $L$ (2018) The Materiality of Mourning, pp. 175-190, Routledge

154. Fernández-Álvarez JP, Rubio-Melendi D, Martínez-Velasco A, Pringle JK, Aguilera HD (2016) Discovery of a mass grave from the Spanish Civil War using Ground Penetrating Radar and forensic archaeology. Forensic Sci lnt 267:e10-e17

155. Loh I, Lian CJ (2019) Non-cremation and mass burial principles in disaster management of human corpse. J Sustain Sci Manage 14(2):117-125

156. Dick HC, Pringle JK (2018) Inorganic elemental analysis of decomposition fluids of an in situ animal burial. Forensic Sci Int 289:130-139

157. Pratt DL, Fonstad TA Livestock mortalities burial leachate chemistry after two years of decomposition, p. 1, American Society of Agricultural and Biological Engineers

158. Kalbasi A, Mukhtar S, Hawkins SE, Auvermann BW (2005) Carcass composting for management of farm mortalities: a review. Compost Sci Util 13(3):180-193

159. Wei W, Chenglong X, Sipeng J, Datao L, Daoqing, H (2006) Removing dioxins from cremation flue gas. Environ Pollut Control 10

160. Huggins TM, Haeger A, Biffinger JC, Ren ZJ (2016) Granular biochar compared with activated carbon for wastewater treatment and resource recovery. Water Res 94:225-232

161. Zhu K, Fu H, Zhang J, Lv X, Tang J, Xu X (2012) Studies on removal of $\mathrm{NH}^{4+}-\mathrm{N}$ from aqueous solution by using the activated carbons derived from rice husk. Biomass Bioenerg 43:18-25

162. Hale S, Alling V, Martinsen V, Mulder J, Breedveld G, Cornelissen G (2013) The sorption and desorption of phosphate-P, ammonium-N and nitrate-N in cacao shell and corn cob biochars. Chemosphere 91(11):1612-1619

163. Liu N, Sun ZT, Wu ZC, Zhan XM, Zhang K, Zhao EF, Han XR (2013) Adsorption characteristics of ammonium nitrogen by biochar from diverse origins in water. Adv Mater Res 664:305-312

164. Sarkhot D, Ghezzehei T, Berhe A (2013) Effectiveness of biochar for sorption of ammonium and phosphate from dairy effluent. J Environ Qual 42(5):1545-1554

165. Zeng Z, Li TQ, Zhao Fl, He Zl, Zhao HP, Yang XE, Wang HI, Zhao J, Rafiq MT (2013) Sorption of ammonium and phosphate from aqueous solution by biochar derived from phytoremediation plants. J Zhejiang Univ Sci B 14(12):1152-1161

166. Hu X, Zhang X, Ngo HH, Guo W, Wen H, Li C, Zhang Y, Ma C (2020) Comparison study on the ammonium adsorption of the biochars derived from different kinds of fruit peel. Sci Total Environ 707:135544

167. Jeong CY, Wang JJ, Dodla SK, Eberhardt TL, Groom L (2012) Effect of biochar amendment on tylosin adsorption-desorption and transport in two different soils. J Environ Qual 41:1185-1192

168. Rajapaksha AU, Vithanage M, Ahmad M, Seo DC, Cho JS, Lee SE, Lee SS, OK YS (2015) Enhanced sulfamethazine removal by steam-activated invasive plant-derived biochar. J Hazard Mater 290:43-50

169. Liu P, Liu WJ, Jiang H, Chen JJ, Li WW, Yu HQ (2012) Modification of bio-char derived from fast pyrolysis of biomass and its application in removal of tetracycline from aqueous solution. Biores Technol 121:235-240 
170. Li C, Zhu X, He H, Fang Y, Dong H, Lü J, Li J, Li Y (2019) Adsorption of two antibiotics on biochar prepared in air-containing atmosphere: influence of biochar porosity and molecular size of antibiotics. J Mol Liq 274:353-361

171. Zhang H, Lu T, Wang M, Jin R, Song Y, Zhou Y, Qi Z and Chen W (2020) Inhibitory role of citric acid in the adsorption of tetracycline onto biochars: effects of solution $\mathrm{pH}$ and $\mathrm{Cu}^{2+}$. Colloids Surfaces A Physicochem Eng Aspects 124731

172. Choi YK, Choi TR, Gurav R, Bhatia SK, Park YL, Kim HJ, Kan E, Yang YH (2020) Adsorption behavior of tetracycline onto Spirulina sp. (microalgae)-derived biochars produced at different temperatures. Sci Total Environ 710:136282

173. Huang J, Zimmerman AR, Chen H, Gao B (2020) Ball milled biochar effectively removes sulfamethoxazole and sulfapyridine antibiotics from water and wastewater. Environ Pollut 258:113809

174. Sadasivam BY, Reddy KR (2015) Adsorption and transport of methane in biochars derived from waste wood. Waste Manage 43:218-229

175. Zhang A, Cui L, Pan G, Li L, Hussain Q, Zhang X, Zheng J, Crowley D (2010) Effect of biochar amendment on yield and methane and nitrous oxide emissions from a rice paddy from Tai Lake plain, China. Agr Ecosyst Environ 139(4):469-475

176. Spokas K, Koskinen W, Baker J, Reicosky D (2009) Impacts of woodchip biochar additions on greenhouse gas production and sorption/ degradation of two herbicides in a Minnesota soil. Chemosphere 77(4):574-581

177. Wang J, Pan X, Liu Y, Zhang X, Xiong Z (2012) Effects of biochar amendment in two soils on greenhouse gas emissions and crop production. Plant Soil 360(1-2):287-298

178. Rogovska N, Laird D, Cruse R, Fleming P, Parkin T, Meek D (2011) Impact of biochar on manure carbon stabilization and greenhouse gas emissions. Soil Sci Soc Am J 75(3):871-879

179. Pokharel P, Kwak JH, Ok YS, Chang SX (2018) Pine sawdust biochar reduces $\mathrm{GHG}$ emission by decreasing microbial and enzyme activities in forest and grassland soils in a laboratory experiment. Sci Total Environ 625:1247-1256

180. Kumar A, Singh E, Khapre A, Bordoloi N, Kumar S (2020) Sorption of volatile organic compounds on non-activated biochar. Bioresour Technol 297:122469

\section{Publisher's Note}

Springer Nature remains neutral with regard to jurisdictional claims in published maps and institutional affiliations.

\section{Submit your manuscript to a SpringerOpen ${ }^{\circ}$ journal and benefit from:}

- Convenient online submission

- Rigorous peer review

- Open access: articles freely available online

- High visibility within the field

- Retaining the copyright to your article 